\title{
Bottom-Up versus Top-Down Induction of Sleep by Zolpidem Acting on Histaminergic and Neocortex Neurons
}

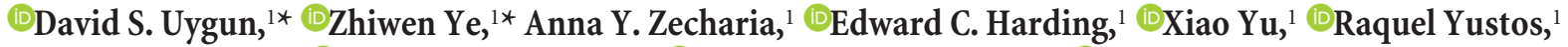

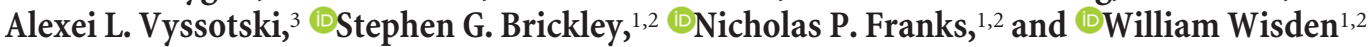 \\ ${ }^{1}$ Department of Life Sciences and ${ }^{2}$ Centre for Neurotechnology, Imperial College London, London SW7 2AZ, United Kingdom, and ${ }^{3}$ Institute of \\ Neuroinformatics, University of Zurich and ETH Zurich, Zurich 8057, Switzerland
}

Zolpidem, a $\mathrm{GABA}_{\mathrm{A}}$ receptor-positive modulator, is the gold-standard drug for treating insomnia. Zolpidem prolongs IPSCs to decrease sleep latency and increase sleep time, effects that depend on $\alpha 2$ and/or $\alpha 3$ subunit-containing receptors. Compared with natural NREM sleep, zolpidem also decreases the EEG power, an effect that depends on $\alpha 1$ subunit-containing receptors, and which may make zolpideminduced sleep less optimal. In this paper, we investigate whether zolpidem needs to potentiate only particular GABAergic pathways to induce sleep without reducing EEG power. Mice with a knock-in F77I mutation in the $\mathrm{GABA}_{\mathrm{A}}$ receptor $\gamma 2$ subunit gene are zolpideminsensitive. Using these mice, $\mathrm{GABA}_{\mathrm{A}}$ receptors in the frontal motor neocortex and hypothalamic (tuberomammillary nucleus) histaminergic-neurons of $\gamma 2 \mathrm{I} 77$ mice were made selectively sensitive to zolpidem by genetically swapping the $\gamma 2 \mathrm{I} 77$ subunits with $\gamma 2 \mathrm{~F} 77$ subunits. When histamine neurons were made selectively zolpidem-sensitive, systemic administration of zolpidem shortened sleep latency and increased sleep time. But in contrast to the effect of zolpidem on wild-type mice, the power in the EEG spectra of NREM sleep was not decreased, suggesting that these EEG power-reducing effects of zolpidem do not depend on reduced histamine release. Selective potentiation of $\mathrm{GABA}_{\mathrm{A}}$ receptors in the frontal cortex by systemic zolpidem administration also reduced sleep latency, but less so than for histamine neurons. These results could help with the design of new sedatives that induce a more natural sleep.

Key words: GABA-A receptor; histamine; insomnia; sleep; tuberomammillary nucleus; zolpidem

Significance Statement

Many people who find it hard to get to sleep take sedatives. Zolpidem (Ambien) is the most widely prescribed "sleeping pill." It makes the inhibitory neurotransmitter GABA work better at its receptors throughout the brain. The sleep induced by zolpidem does not resemble natural sleep because it produces a lower power in the brain waves that occur while we are sleeping. We show using mouse genetics that zolpidem only needs to work on specific parts and cell types of the brain, including histamine neurons in the hypothalamus, to induce sleep but without reducing the power of the sleep. This knowledge could help in the design of sleeping pills that induce a more natural sleep.

\section{Introduction}

Many healthy people who cannot sleep, as well as many with neurological or mental illness, take sedatives (Wafford and Ebert, 2008; Winsky-Sommerer, 2009; Nutt and Stahl, 2010; Mignot,

Received Oct. 9, 2015; revised Aug. 16, 2016; accepted Aug. 17, 2016.

Author contributions: D.S.U.,Z.Y., S.G.B., N.P.F., and W.W. designed research;D.S.U., Z.Y., A.Y.Z., E.C.H.,X.Y., and R.Y. performed research; X.Y. and A.L.V. contributed unpublished reagents/analytic tools; D.S.U., Z.Y., A.Y.Z., S.G.B., N.P.F., and W.W. analyzed data; D.S.U., Z.Y., S.G.B., N.P.F., and W.W. wrote the paper.

This work was supported by Biotechnology and Biological Sciences Research Council studentship to D.S.U., Biotechnology and Biological Sciences Research Council Grant BB/K018159/1 to S.G.B., N.P.F., and W.W., Medical Research Council Grant G0901892 to S.G.B., N.P.F., and W.W., Medical Research Council Grant G0800399 to W.W., Wellcome Trust WT094211MA to S.G.B., N.P.F., and W.W., Joint Investigator Award 107839/Z/15/Z to N.P.F., Joint Investigator Award 107841/Z/15/Z to W.W., Biotechnology and Biological Sciences Research Council Doctoral Training Grant BB/F017324/1 to E.C.H., and a United Kingdom-China Scholarships for Excellence/China Scholarship scheme to X.Y. and Z.Y.

The authors declare no competing financial interests.

This article is freely available online through the J Neurosci Author Open Choice option.

${ }^{*}$ D.S.U. and Z.Y. contributed equally to this work.
2013; Rihel and Schier, 2013). Zolpidem (Ambien), a nonbenzodiazepine $\mathrm{GABA}_{\mathrm{A}}$ receptor-positive modulator, is currently the most successful "sleeping pill" (Nutt and Stahl, 2010). In the United States alone, there were 53.4 million prescriptions for

Correspondence should be addressed to either Dr. Nicholas P. Franks or Dr. William Wisden, Department of Life Sciences, Imperial College London, London SW7 2AZ, UK. E-mail: w.wisden@imperial.ac.uk or n.franks@imperial.ac.uk.

D.S. Uygun's present address: Harvard Medical School Department of Psychiatry, West Roxbury, Massachusetts 02132

Z. Ye's present address: The Francis Crick Institute, Mill Hill Laboratory, The Ridgeway, Mill Hill, London NW7 1AA, United Kingdom.

A.Y. Zecharia's present address: British Pharmacological Society, The Schild Plot, London EC1V 2PT, United Kingdom.

D0I:10.1523/JNEUROSCI.3714-15.2016

Copyright $\odot 2016$ Uygun, Ye, et al.

This is an Open Access article distributed under the terms of the Creative Commons Attribution License Creative Commons Attribution 4.0 International, which permits unrestricted use, distribution and reproduction in any medium provided that the original work is properly attributed. 
Table 1. Time and percentage of time spent in Wake, NREM, and REM sleep for the different types of mice used in the study ${ }^{a}$

\begin{tabular}{|c|c|c|c|c|c|c|c|c|c|}
\hline \multirow[b]{2}{*}{ Genotype } & \multicolumn{3}{|l|}{ Wake } & \multicolumn{3}{|l|}{ NREM } & \multicolumn{3}{|l|}{ REM } \\
\hline & Time (min) & $\%$ & SEM & Time (min) & $\%$ & SEM & Time (min) & $\%$ & SEM \\
\hline C57BL/6J & 68.83 & 57.88 & 10.38 & 44.25 & 37.17 & 8.00 & 5.92 & 4.96 & 3.01 \\
\hline$H D C-\gamma 2 F 77$ & 71.58 & 60.72 & 5.86 & 39.08 & 33.23 & 5.96 & 7.08 & 6.05 & 1.56 \\
\hline$F(-\gamma 2 F 77$ & 54.83 & 47.08 & 3.48 & 54.50 & 46.68 & 3.50 & 7.33 & 6.24 & 1.38 \\
\hline SC- $\gamma 2 F 77$ & 64.17 & 56.12 & 6.21 & 46.21 & 40.45 & 0.97 & 3.92 & 3.43 & 1.73 \\
\hline
\end{tabular}

${ }^{a}$ The data were recorded over a baseline period of $2 \mathrm{~h}$. One-way ANOVA revealed no significant differences between the mouse types for Wake, NREM, or REM sleep.

zolpidem in 2010 (Greenblatt and Roth, 2012). The drug decreases sleep latency, the time to the onset of NREM sleep (Arbilla et al., 1985; Gottesmann et al., 1998; Alexandre et al., 2008; Anaclet et al., 2012; Xu et al., 2014). After taking a $10 \mathrm{mg}$ tablet of zolpidem, the average person goes to sleep after $\sim 12 \mathrm{~min}$ (Greenblatt and Roth, 2012). Compared with natural (drug-free) NREM sleep, however, the NREM sleep induced by zolpidem has reduced power in most EEG frequencies (Landolt et al., 2000; Kopp et al., 2004; Alexandre et al., 2008). This reduced power may indicate that zolpidem-induced sleep is suboptimal compared with natural NREM sleep.

Zolpidem works at three $\mathrm{GABA}_{\mathrm{A}}$ receptor subtypes: $\alpha 1 \beta \gamma 2$, $\alpha 2 \beta \gamma 2$, and $\alpha 3 \beta \gamma 2$ (Pritchett and Seeburg, 1990; Crestani et al., 2000; Cope et al., 2004; Kopp et al., 2004; Leppä et al., 2011), and has the highest affinity at $\alpha 1$-containing receptors (Pritchett and Seeburg, 1990). These $\alpha 1 \beta \gamma 2$-containing receptors are expressed widely (Niddam et al., 1987; Wisden et al., 1988, 1992; Pritchett et al., 1989; Duncan et al., 1995; Fritschy and Mohler, 1995; Hörtnagl et al., 2013). Surprisingly, the $\alpha 1$-containing GABA receptors are not responsible for zolpidem's ability to promote sleep. In mice with $\alpha 1$ subunits made insensitive to zolpidem by a mutation, H101R, zolpidem reduces latency to NREM sleep and prolongs NREM sleep time as well as it does in wild-type mice (Kopp et al., 2004). Thus, zolpidem's sleep-promoting effects come from enhancing GABA's actions at $\mathrm{GABA}_{\mathrm{A}}$ receptors with $\alpha 2$ and/or $\alpha 3$ subunits. Instead, the $\alpha 1 \mathrm{H} 101 \mathrm{R}$ mice do show that $\alpha 1$-containing receptors are needed for zolpidem to produce its characteristic decrease in the EEG power in NREM sleep (Kopp et al., 2004). But can zolpidem potentiate $\alpha 2$ and/or $\alpha 3$-containing receptors in only particular GABA pathways to induce sleep without reducing EEG power? The answer could help design sedatives that produce a more natural sleep.

Natural NREM sleep is hypothesized to start when GABA neurons in the preoptic hypothalamus increase their activity onto, among other targets, the wake-promoting histaminergic neurons in the tuberomammillary nucleus (TMN) of the posterior hypothalamus (Nitz and Siegel, 1996; Sherin et al., 1996, 1998; Zhang et al., 2015). Infusing the $\mathrm{GABA}_{\mathrm{A}}$ agonist muscimol into this area induces sleep (Lin et al., 1989; Nitz and Siegel, 1996); conversely, injecting $\mathrm{GABA}_{\mathrm{A}}$ receptor antagonists there decreases the potency of GABAergic anesthetics (Nelson et al., 2002). Thus, $\mathrm{GABA}_{\mathrm{A}}$ receptor modulators, such as zolpidem, could produce sleep by decreasing histaminergic activity (Nelson et al., 2002). Histaminergic neurons express $\alpha 1 \beta 3 \gamma 2$ and $\alpha 2 \beta 3 \gamma 2$ $\mathrm{GABA}_{\mathrm{A}}$ receptors (Fritschy and Mohler, 1995; Sergeeva et al., 2002; Zecharia et al., 2009, 2012; May et al., 2013); and so, GABA receptors on these neurons could, in part, account either for the EEG power-reducing effect of zolpidem ( $\alpha 1$-containing receptors), or critically, the ability of zolpidem to reduce latency to NREM sleep and increase sleep time ( $\alpha 2$-containing receptors).

We previously used a pharmacogenetics method, based on mutated $\mathrm{GABA}_{\mathrm{A}}$ receptors, for probing how endogenous GABA inputs onto selected cell types generates behavior (Wulff et al.,
2007; Wisden et al., 2009; Sieghart, 2012). The mutation F77I in the $\gamma 2$ subunit $(\gamma 2 \mathrm{I} 77)$ abolishes zolpidem binding to $\mathrm{GABA}_{\mathrm{A}}$ receptors (Buhr et al., 1997; Wingrove et al., 1997; Cope et al., 2004). In $\gamma 2 \mathrm{I} 7^{\text {lox }}$ mice, the zolpidem-insensitive $\gamma 2 \mathrm{I} 77$ subunits can be swapped with zolpidem-sensitive $\gamma 2$ F77 versions (Wulff et al., 2007). Here, using this method, we found that strengthening inhibition onto histamine neurons by zolpidem induces NREM sleep but does not reduce EEG power.

\section{Materials and Methods}

Mice. All experiments were performed in accordance with the United Kingdom Home Office Animal Procedures Act (1986); all procedures were approved by the Imperial College Ethical Review Committee. All mice weighed between 19 and $30 \mathrm{~g}$ and were $\sim 17$ weeks old at the time of AAV injections. Both male and female mice were used, but no sex differences were observed and the data were pooled. The sleep-wake studies and drug administrations were started $\sim 4$ weeks after AAV injection (see below). Adult C57BL/6J mice were purchased from Harlan. The $H D C$ $\Delta \gamma 2 I 77$ mice were produced by crossing HDC-Cre (JAX stock \#021198, RRID:IMSR_JAX:021198) and $\gamma 2 I 77^{l o x}$ _ (zolpidem-insensitive) mice (JAX stock \#021197, RRID:IMSR_JAX:021197) on C57BL/6J backgrounds, as described previously (Zecharia et al., 2012). In adult HDCCre mice, Cre recombinase expression is driven by the endogenous $h d c$ gene and is found selectively in histaminergic neurons in the TMN, and mast cells in the rest of the brain; the knock-in HDC-Cre allele expresses functional HDC protein (Zecharia et al., 2012). In the $\gamma 2 I 77^{\text {lox }}$-mice, exon 4 of the $\mathrm{GABA}_{\mathrm{A}}$ receptor $\gamma 2$ subunit gene ( gabrg2), which encodes the critical I77 residue, is flanked by loxP sites (Wulff et al., 2007); deletion of exon 4 by Cre recombinase produces a null gabrg2 allele (Wulff et al., 2007, 2009a, b; Rovó et al., 2014). The baseline vigilance-state data (\% Wake, NREM, and REM) recorded for a $2 \mathrm{~h}$ period, as determined by EEG/EMG scoring, for the mice in drug-free conditions are shown in Table 1 (see EEG recordings and sleep scoring).

Generation of HDC- $\gamma 2 \mathrm{~F} 77, \mathrm{FC}-\gamma 2 \mathrm{~F} 77$, and superior colliculi (SC) SC$\gamma 2 \mathrm{~F} 77$ mice. Stereotaxic injections of AAV were performed with a Leica Angle Two frame under isoflurane anesthesia, using Hamilton microliter $\# 70110 \mu \mathrm{l}$ syringes with adjoining capillary glass pipettes tapered $1 \mathrm{~mm}$ to $\sim 50 \mu \mathrm{m}$ diameter, back-loaded with mineral oil and AAV mixture (1:1 with $20 \%$ mannitol) in the tip (see AAV transgenes and AAV production). The coordinates of the (bilateral) injection sites according to the digital atlas of the Leica apparatus were, relative to bregma: frontal cortex (FC) of $\gamma 2 \mathrm{I} 77^{\text {lox }}$ mice (mediolateral \pm 1.75 , anteroposterior 1.87, dorsoventral $-1.70(\mathrm{~mm}), 1.5 \mu \mathrm{l} A A V$-Cre-2A- $\gamma 2 \mathrm{~F} 77$ and AAV-flex-revEGFP suspension per side, with the two AAVs mixed 1:1 before injection); SC of $\gamma 2 I 77^{l o x}$ mice (mediolateral \pm 1 , anteroposterior -3.88 , dorsoventral $-2(\mathrm{~mm}), 1 \mu \mathrm{l} A A V$-Cre- $2 A-\gamma 2 F 77$ suspension per side); TMN of HDC- $\Delta \gamma 2 I 77$ mice (mediolateral \pm 0.92 , anteroposterior -2.70 , dorsoventral -5.34 (mm), $1.5 \mu \mathrm{lAAV}$ - flex-rev- $\gamma 2 F 77-2 A$-Venus suspension per side). After AAV injections, the mice recovered for a minimum of 4 weeks in their home cages. The baseline vigilance-state data (\% Wake, NREM, and REM), as determined by EEG/EMG scoring, for the HDC- $\gamma 2 F 77, F C-\gamma 2 F 77$, and $S C-\gamma 2 F 77$ mice in drug-free conditions for a $2 \mathrm{~h}$ period are shown in Table 1 (see EEG recordings and sleep scoring).

$A A V$ transgenes and $A A V$ production. The $A A V$-panpromoter-flex-revVenus-2A- $\gamma 2 F 77$ transgene was constructed from components of $p A A V$ $C A G$-promoter-Cre- $2 A-\gamma 2 F 77$, kindly provided by Zoltan Nusser, 
A

C57BL/6

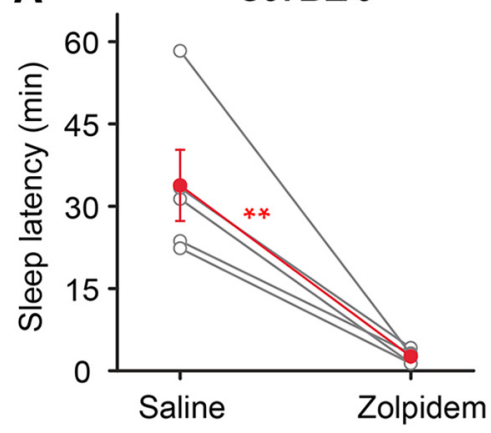

B

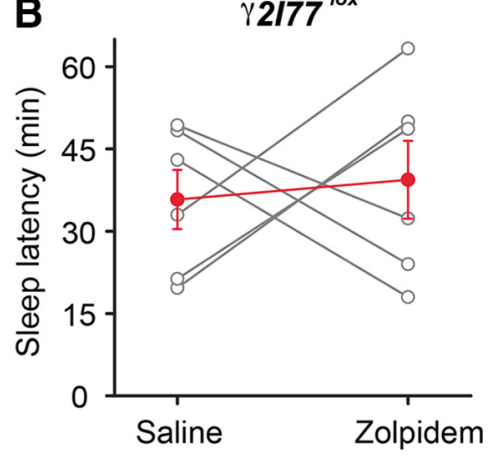

C

C57BL/6

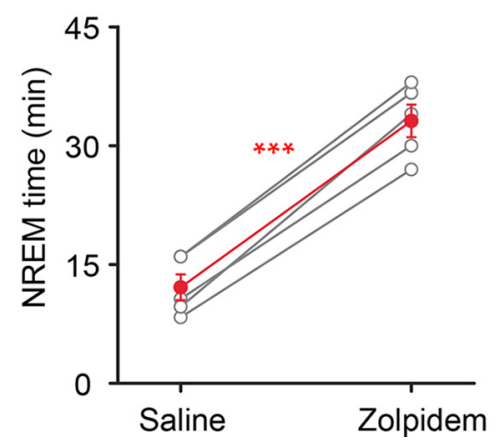

D

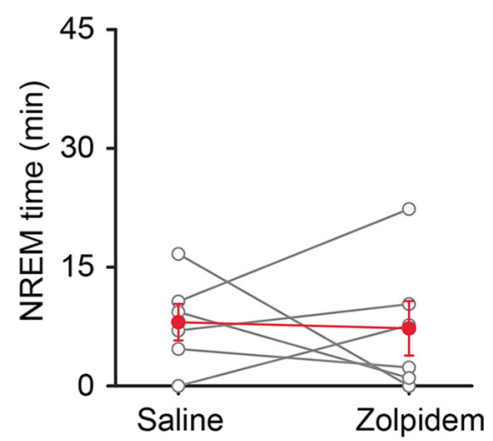

Figure 1. Zolpidem reduces sleep latency and increases sleep time in (57BL/6J but not in $\gamma 2177^{10 x}$ mice. Sleep latencies after saline and zolpidem (5 mg/kg) injections in $\left(57 B L / 6 J(A)\right.$ and $\gamma 2177^{10 x}(B)$ mice. For $\left(57 B L / 6 J\right.$ mice: ${ }^{* *} p=0.008$ (paired $t$ test). C, Time spent in NREM sleep in the first 45 min after saline and zolpidem in C57BL/6J (C) and $\gamma 2177^{\text {lox }}(\boldsymbol{D})$ mice. For C57BL/6J mice: ${ }^{* * *} p=0.0003$ (paired $t$ test).

Institute of Experimental Medicine, Hungarian Academy of Sciences, Budapest, Hungary (Sumegi et al., 2012); and pAAV-flex-rev-hM4$m$ Cherry (Addgene plasmid 44362, gift of Bryan Roth, University of North Carolina at Chapel Hill, NC (Krashes et al., 2011), Addgene, RRID:SCR_002037). The "panpromoter" in the AAV-panpromoter-flexrev- $\gamma 2 F 77-2 A-V e n u s$ transgene was derived from a fragment of the promoter of the mouse histidine decarboxylase $(h d c)$ gene; we originally hoped that this $h d c$ promoter fragment would be selective for histaminergic cells but found that it worked well in all neuronal cell types we tested (unpublished data). The AAV-panpromoter-flex-rev- 2 2F77-2A-Venus transgene plasmid has been deposited at Addgene (Addgene Plasmid 71410, Addgene, RRID:SCR_002037). The AAV-flex-rev-EGFP transgene was Addgene plasmid 28304 (gift from Edward Boyden, Massachusetts Institute of Technology, Cambridge, MA). The AAV transgenes $A A V$-flex-rev- $\gamma 2$ F77-2A-Venus, $A A V$-Cre- $2 A-\gamma 2 F 77$, and $A A V$-flex-rev$E G F P$ were each packaged in AAV1/2 capsids and purified with heparin columns (Klugmann et al., 2005). AAV was suspended in sterile PBS at $1: 1$ concentration.

EEG recordings and sleep scoring. For nontethered EMG and EEG recordings, mice were fitted with Neurologger 2 A devices (Anisimov et al., 2014). The recordings took place in home cages. Data were sampled at $200 \mathrm{~Hz}$ and downloaded offline and processed with Spike2 software (Cambridge Electronic Design, Spike2 Software, RRID:SCR_000903). The EEG was high-pass filtered $(0.5 \mathrm{~Hz}$ corner frequency, $-3 \mathrm{~dB})$. The EMG was bandpass filtered $(5-45 \mathrm{~Hz},-3 \mathrm{db})$. Wake, non-REM, and REM were first automatically sleep-scored using previously described criteria (Costa-Miserachs et al., 2003). The EEG results were then manually verified.

To calculate power spectra, segments of NREM identified after sleep scoring were concatenated and power spectra calculated using a Fast Fourier transform with a Hanning window function. Segments of data of at least $10 \mathrm{~min}$ were used. The power spectra were normalized as we described previously, such that the area under the saline controls for a

given genotype was unity (Zhang et al., 2015). Power changes were computed as differences in areas under the power spectra.

Behavioral experiments and drug administration. Mice were maintained on a $12 \mathrm{~h}$ light/ $12 \mathrm{~h}$ dark cycle with ad libitum food and water. All behavioral experiments took place during the "lights off" part of the cycle when the mice were most active. In all cases, we used paired comparisons where the animals served as their own controls, a withinanimals approach (crossover design). The experimenters were not blinded to treatment. Zolpidem (Tocris Biosciences) was dissolved in equimolar tartaric acid $(\mathrm{BDH}$ Chemicals) in $0.9 \% \mathrm{w} / \mathrm{v}$ saline.

Immunohistochemistry. Mice were anesthetized with pentobarbital and transcardially perfused with PBS followed by $4 \%$ PFA. Brains were submerged in 4\% PFA overnight and stored in $30 \%$ sucrose. Free-floating sections $(40 \mu \mathrm{m})$ were blocked with $10 \%$ normal goat serum, $1 \%$ BSA, $0.1 \%$ Triton $\mathrm{X}$ in PBS ( $2 \mathrm{~h}$, room temperature). Sections were incubated for $24-48 \mathrm{~h}$ at $4^{\circ} \mathrm{C}$ with primary antisera: rabbit anti-Cre (1:1000; Novagen), or rabbit anti-GFP (1:1000; Stratagene), or rabbit streptavidin (1:1000; Alexa-Fluor-555 conjugate; Invitrogen). Secondary goat antirabbit antisera (Alexa-Fluor-488 or 594, 1:1000; Invitrogen) were incubated for $2 \mathrm{~h}$ at room temperature. Pictures were taken using a Nikon eclipse 80i microscope with Qcapture Pro software (Q Capture software, RRID:SCR_014432), or a Zeiss Cell Observer Live Cell Imaging System, or a Zeiss LSM 510 inverted microscope with Zen pro software. Images were processed using ImageJ (open source, ImageJ, RRID: SCR_003070) and Adobe Photoshop (Adobe Photoshop CS6, RRID: SCR_014199).

Quantifying the spread of AAV transduction. For the HDC- $\gamma 2 F 77$ mice, Venus-positive neurons were counted on fixed sections using ImageJ. Signal-emitting outliers ( $<15 \mu \mathrm{m}$ or $>30 \mu \mathrm{m}$ diameter $)$ were excluded, as were objects visually scored as incorrect (e.g., microglia). For the FC$\gamma 2 F 77$ and $S C-\gamma 2 F 77$ mice, Cre-positive neurons were identified by immunohistochemistry, and the percentage area of the target region (FC or SC) was calculated, again using ImageJ (ImageJ, RRID:SCR_003070).

Brain-slice electrophysiology. We recorded spontaneous IPSCs from whole-cell, voltage-clamped, HDC neurons of the TMN and pyramidal neurons of the FC in acute slices. Brains were rapidly removed and immersed in ice-cold slicing ACSF $(85 \mathrm{~mm} \mathrm{NaCl}, 2.5 \mathrm{~mm} \mathrm{KCl}, 1 \mathrm{~mm} \mathrm{CaCl}$, $5 \mathrm{~mm} \mathrm{MgCl}_{2}, 1.25 \mathrm{~mm} \mathrm{NaH}_{2} \mathrm{PO}_{4}, 26 \mathrm{~mm} \mathrm{NaHCO}_{3}, 75 \mathrm{~mm}$ sucrose, $11 \mathrm{~mm}$ glucose, bubbled with $95 \% \mathrm{O}_{2} / 5 \% \mathrm{CO}_{2}$ ). For the TMN, a tissue block was cut between the cerebellum and optic tract, and coronal sections were cut to a thickness of $250 \mu \mathrm{m}$ on a vibratome. For the FC, a tissue block was cut between the optic tract and $\sim 1 \mathrm{~mm}$ behind the olfactory bulb. After slicing, the holding chamber was transferred to a $37^{\circ} \mathrm{C}$ heat block for 15 min, and slicing ACSF was gradually exchanged for recording ACSF (125 mм NaCl, $2.5 \mathrm{~mm} \mathrm{KCl,} 2 \mathrm{~mm} \mathrm{CaCl}, 1 \mathrm{~mm} \mathrm{MgCl} 2,1.25 \mathrm{~mm} \mathrm{NaH}_{2} \mathrm{PO}_{4}, 26$ mM $\mathrm{NaHCO}_{3}$, and $11 \mathrm{~mm}$ glucose, pH 7.4, bubbled with $95 \% \mathrm{O}_{2} / 5 \%$ $\mathrm{CO}_{2}$ ) over $40 \mathrm{~min}$. Electrophysiological recordings were made at room temperature. We identified histaminergic neurons by the presence of hyperpolarization-activated currents ( $\mathrm{h}$ ), a transient outward current, and the spontaneous firing activity of the cells (Stevens et al., 2001). Virally transduced pyramidal neurons in the FC were found by Credependent expression of EGFP. Pyramidal neurons were identified primarily by morphology. For detection of IPSCs, we performed whole-cell recordings in voltage-clamp $(-70 \mathrm{mV})$ using internal pipette solutions containing the following: $140 \mathrm{~mm} \mathrm{CsCl}, 4 \mathrm{~mm} \mathrm{NaCl}, 0.5 \mathrm{mM} \mathrm{CaCl}_{2}, 10 \mathrm{~mm}$ 
A

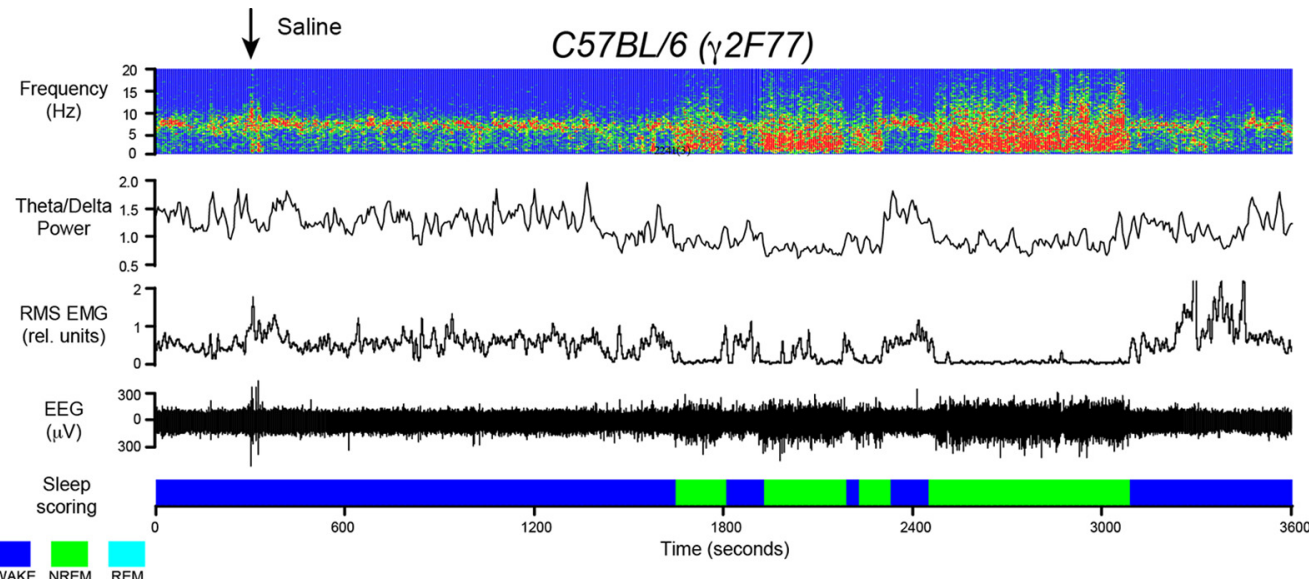

$\downarrow 5 \mathrm{mgs} / \mathrm{kg}$ Zolpidem

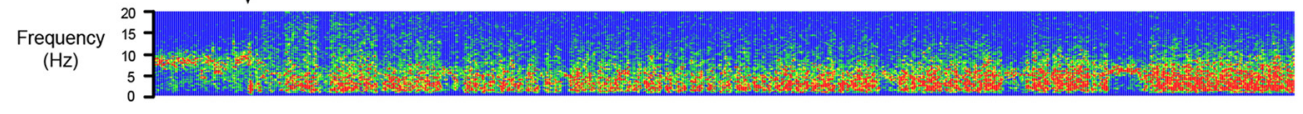

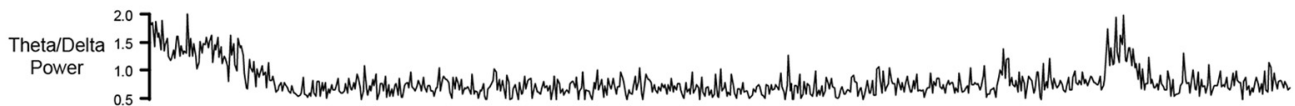
$\begin{array}{ll}\text { RMS EMG } & 2 \\ \text { (rel. units) } & 1 \\ 0\end{array}$

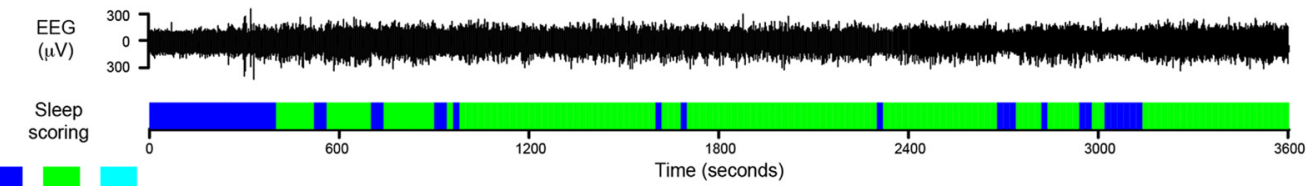

\section{B}

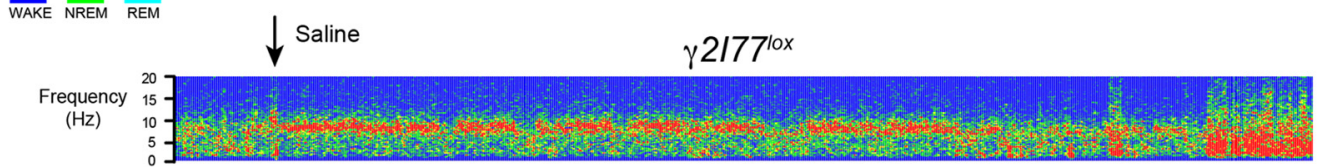

$$
\begin{gathered}
\text { Theta/Delta } \\
\text { Power } \\
1.0 .
\end{gathered}
$$

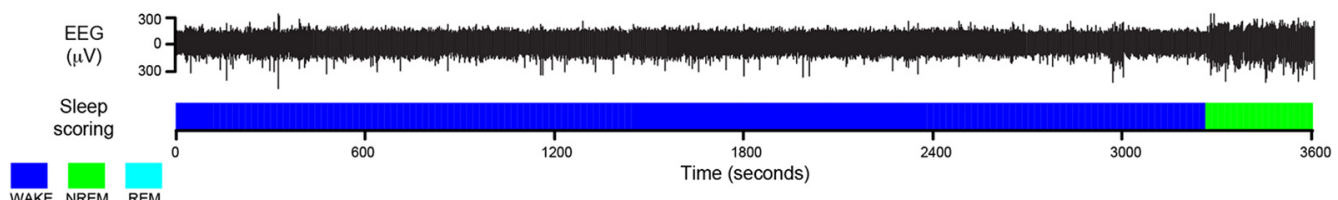

WAKE NREM REM $\downarrow 5$ mgs $/ \mathrm{kg}$ Zolpidem

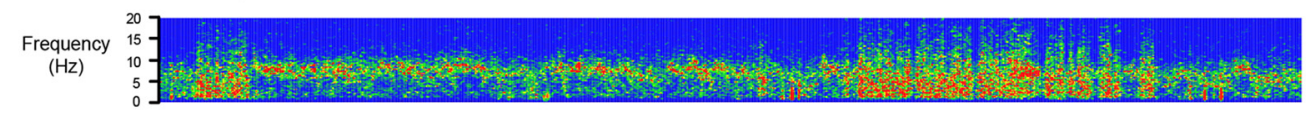

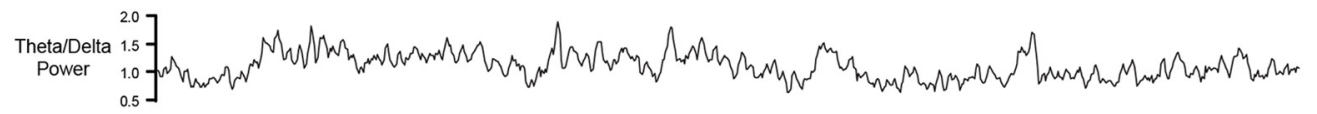

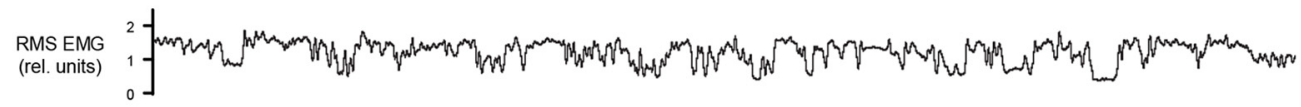

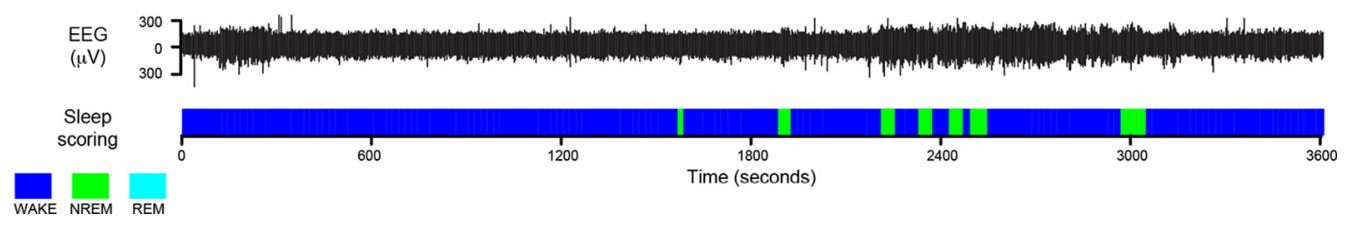


HEPES, 5 mm EGTA, and $2 \mathrm{~mm} \mathrm{Mg-ATP;} \mathrm{the} \mathrm{pH}$ was adjusted to 7.3 with $\mathrm{CsOH}$.

Statistical analysis. For behavioral and EEG comparisons, and comparisons of IPSC decay times from the electrophysiology analysis, we used two-tailed paired $t$ tests (Janusonis, 2009), and normality was assumed. Analyses were performed in OriginPro 8.6 or GraphPad Prism 4.03 (GraphPad Prism, RRID:SCR_002798).

\section{Results}

Zolpidem does not induce sleep in $\gamma 2177^{\text {lox }}$ mice

The wild-type $\gamma 2$ subunit ( $\gamma 2$ F77) confers zolpidem sensitivity on $\alpha 1 \beta, \alpha 2 \beta$, and $\alpha 3 \beta$ subunit-containing $\mathrm{GABA}_{\mathrm{A}}$ receptors (Pritchett et al., 1989; Pritchett and Seeburg, 1990; Günther et al., 1995). The binding site for zolpidem, at the interface between the $\alpha$ and $\gamma 2$ subunits, requires residue F77 in the $\gamma 2$ subunit (Buhr et al., 1997; Wingrove et al., 1997). Changing the F77 residue to I (F77I) abolishes zolpidem binding. Consequently, knock-in mice with the $\gamma 2$ point mutation $\gamma 2$ F77I ( $\gamma 2 I 77^{l o x}$ mice) are behaviorally insensitive to zolpidem in the dose range $1-30 \mathrm{mg} / \mathrm{kg}$ (Cope et al., 2004; Wulff et al., 2007; Leppä et al., 2011). However, EEG and sleep responses of $\gamma 2 I 77^{l o x}$ mice following zolpidem administration have not been investigated. C57BL/6J mice and $\gamma 2 I 77^{l o x}$ mice showed no difference in their baseline sleep parameters (Table 1). We then established how zolpidem (5 mg/kg), compared with a saline injection, influenced latency to NREM-like sleep and total sleep time in $C 57 B L / 6 \mathrm{~J}$ mice and $\gamma 2 I 77^{l o x}$ mice. Zolpidem at $5 \mathrm{mg} / \mathrm{kg}$ (systemic injection, i.p.) caused $C 57 B L / 6 J$ $(\gamma 2$ F77 $)$ mice to enter NREM sleep in $2.6 \pm 0.6 \mathrm{~min}(n=5$; paired $t$ test, $t_{(4)}=4.9, p=0.008$ ) (Fig. 1A), whereas at this dose of zolpidem, $\gamma 2 I 77^{l o x}$ mice did not fall asleep for $39 \pm 7 \mathrm{~min}(n=$ 6; paired $t$ test, $t_{(5)}=0.31, p=0.77$ ) (Fig. $1 B$ ), which was approximately the same time they and $C 57 B L / 6 \mathrm{~J}$ mice took to fall into NREM sleep following a saline injection (Fig. $1 A$ ). In $C 57 B L / 6 J$ mice, in the first 45 min after injection, zolpidem more than doubled the amount of NREM-like sleep over baseline (from $12 \pm 1.6 \mathrm{~min}$ to $33 \pm 2 \mathrm{~min} ; n=5$; paired $t$ test $t_{(4)}=20.77, p=$ 0.0003; Fig. 1C). The effect persisted until at least $90 \mathrm{~min}$ after injection. These data, reduced sleep latency and prolonged sleep time, are consistent with previous reports on zolpidem's action in C57BL/6J mice (Kopp et al., 2004; Alexandre et al., 2008). By contrast, there was no change in the sleep time above baseline in zolpidem-injected $\gamma 2 I 77^{l o x}$ mice $\left(n=6\right.$ paired $t$ test, $t_{(5)}=0.18$, $p=0.86$; Fig. $1 D$ ). Examples of the primary EEG/EMG recordings for saline- and zolpidem-injected C57BL/6 ( $\gamma 2 F 77)$ and $\gamma 2 I 77^{l o x}$ mice are shown in Figure 2.

In agreement with previous studies (Kopp et al., 2004; Alexandre et al., 2008), we found that the power of "NREM sleep" produced by zolpidem in $C 57 B L / 6 \mathrm{~J}$ mice was lower than that found in natural NREM sleep. Zolpidem reduced power during NREM sleep (Fig. 3A) over the frequency range between 5 and 16 $\mathrm{Hz}\left(n=5\right.$, paired $t$ test, $\left.t_{(4)}=4.5, p=0.01\right)$. In $\gamma 2 I 77^{\text {lox }}$ mice, zolpidem injection did not change the EEG power spectrum in either the waking (Fig. 3B) or NREM (Fig. 3C) states.

Figure 2. EEG spectra and sleep scoring for zolpidem-induced sleep in $C 57 B L / 6(\gamma 2 F 77)$ mice compared with $\gamma 2177^{\text {lox }}$ mice. $A$, EEG power spectra for $(57 B L / 6 J$ mice injected with saline or 5 $\mathrm{mg} / \mathrm{kg}$ zolpidem. The spectra are aligned in register with the $\theta / \delta$ power ratio, the root mean square electromyogram (RMS EMG), the primary EEG, and the sleep scoring assignments (Wake, NREM, REM). Arrow indicates the time of saline or zolpidem injection. $\boldsymbol{B}$, EEG power spectra for $\gamma 2177^{\text {lox }}$ mice injected with saline or $5 \mathrm{mg} / \mathrm{kg}$ zolpidem. All alignments of traces are as above in $\boldsymbol{A}$.
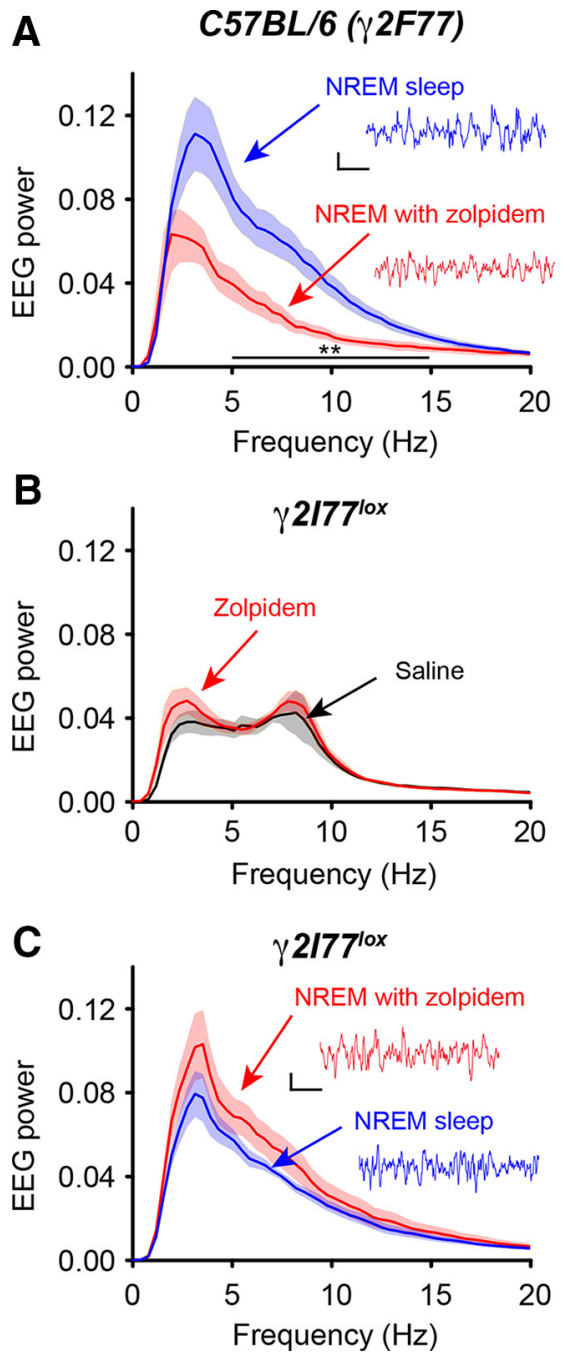

Figure 3. Zolpidem does not induce sleep in $\gamma 2177^{10 x}$ mice-EEG power analysis. $\boldsymbol{A}$, EEG power spectrum of natural NREM sleep (blue) or zolpidem-induced sleep ( $5 \mathrm{mg} / \mathrm{kg}$, red) in C57BL/6J $(\gamma 2 F 77)$ mice. Zolpidem reduced power during NREM sleep (Fig. 3A) over the frequency range between $5 \mathrm{~Hz}$ and $16 \mathrm{~Hz}\left(n=5\right.$, paired $t$ test, $\left.t_{(4)}=4.5, p=0.01\right)$. $\boldsymbol{B}$, EEG power spectrum of $\gamma 2177^{10 x}$ mice $(n=6)$ in the waking state following saline intraperitoneal injection (black) or zolpidem (5 mg/kg i.p.; red). C, In $\gamma 2177^{\text {lox }}$ mice, zolpidem does not influence the power spectra during NREM sleep. Typical epochs of EEG trace are shown. Calibration: $\boldsymbol{A}, \boldsymbol{C}, 200$ $\mu \mathrm{V}, 500 \mathrm{~ms}$.

\section{Potentiation of GABA inputs onto histaminergic neurons by} zolpidem induces and maintains NREM sleep

Having demonstrated that $\gamma 2 I 77^{l o x}$ mice do not enter NREM sleep after systemic zolpidem administration, we next made several areas of the brains of $\gamma 2 I 77^{l o x}$ mice zolpidem-sensitive using the $\gamma 2 \mathrm{I} 77$ to $\gamma 2 \mathrm{~F} 77$ subunit switch. The first target was histamine neurons. Previously, we generated and studied HDC- $\Delta \gamma 2 I 77$ mice, which are mice with a deletion of the $\gamma 2 I 77$ subunit from histaminergic neurons in the TMN, obtained by crossing HDCCre and $\gamma 2 I 77^{l o x}$ mice (Zecharia et al., 2012). The histaminergic neurons of these HDC- $\Delta \gamma 2 I 77$ mice lack IPSCs (Zecharia et al., 2012). Because the HDC- $\Delta \gamma 2 I 77$ mice still had Cre recombinase expressed in their histaminergic neurons, we could implement a "restorative genetics" strategy and put the $\gamma 2$ F77 subunit back into the neurons from which the $\gamma 2 \mathrm{I} 77$ version was deleted. We introduced the zolpidem-sensitive $\gamma 2 \mathrm{~F} 77$ subunit into the histaminergic neurons of HDC- $\Delta \gamma 2 I 77$ mice using a Cre recombinase flex switch-dependent transgene (Atasoy et al., 2008), flex-rev- 
A

Mouse

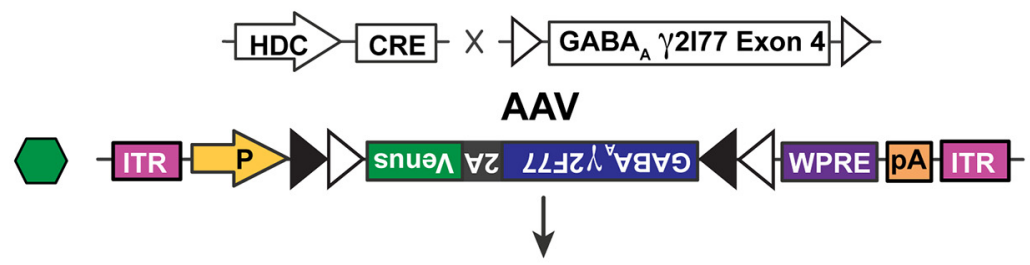

GABA $_{A} \gamma 2177$ Exon 4 deleted

ITR P ${ }_{\text {GABA }}$ Y2F77 2A Venus WPRE PA ITR -

Transgenically expressed:

AAV

$\mathrm{GABA}_{\mathrm{A}}$ Y 2F77 + Venus
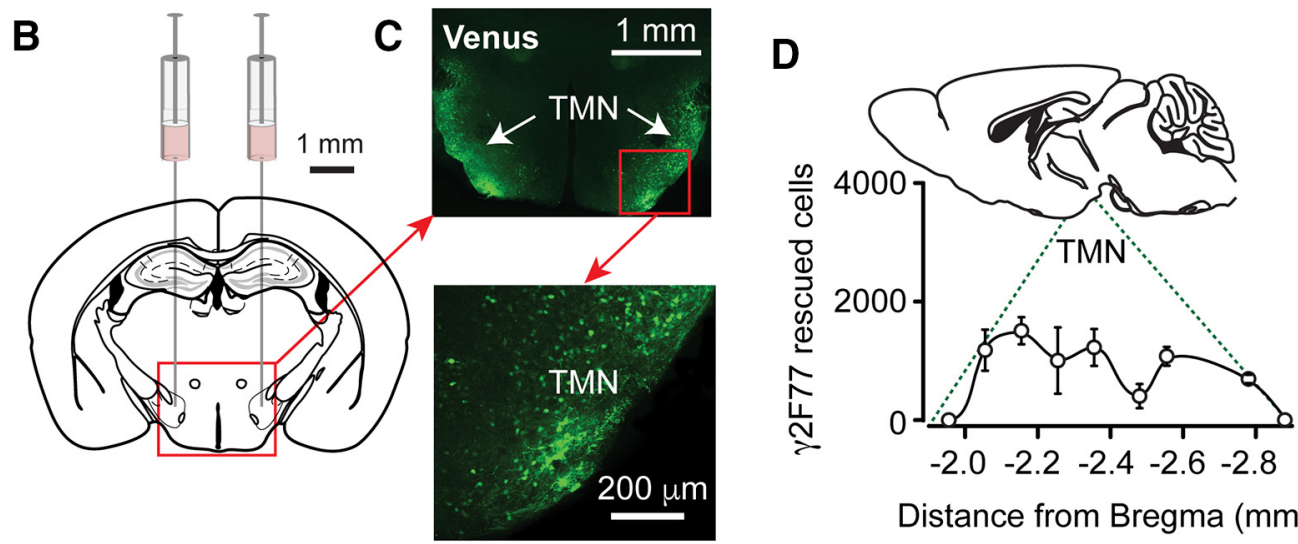

E

C57BL/6
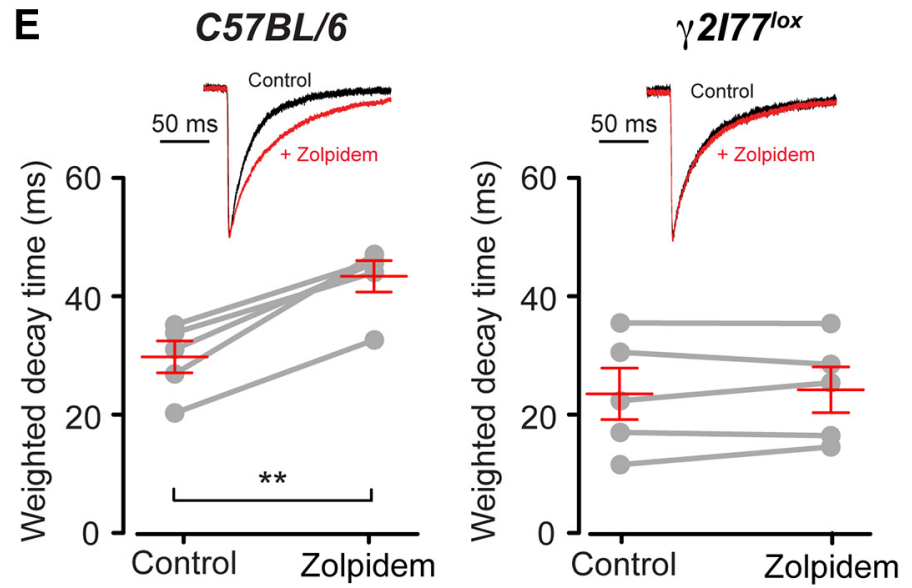

Distance from Bregma $(\mathrm{mm})$

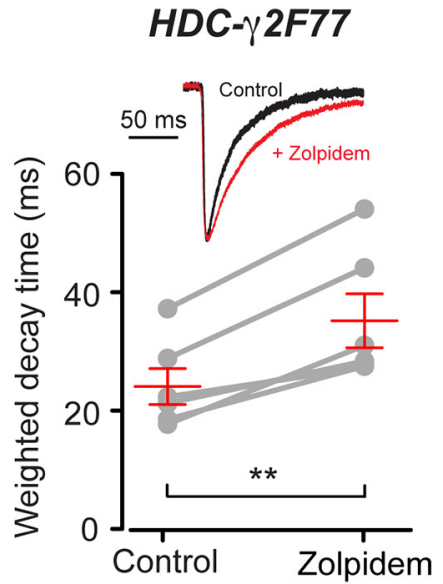

Figure 4. Making histamine neurons selectively sensitive to zolpidem. $A$, Generating the HDC- $\gamma 2 F 77$ mice: the alleles HDC-Cre and $\gamma 2177^{10 x}$ in HDC- $\Delta \gamma 2177$ mice, and the AAV flex-switch transgene construct $A A V$-flex-rev- $\gamma 2 F 77-2 A$-Venus used to selectively label (Venus) and introduce zolpidem sensitivity ( $\gamma 2 F 77$ ) in HDC- $\Delta$ y2l77 neurons. Open triangles represent $10 x P$ sites. Filled triangles represent Iox2272 sites. ITR, Inverted terminal repeats; P, pan-promoter (hdc gene promoter fragment); WPRE, woodchuck post-transcriptional regulatory element. B, Schematic of AAV microinjection into the TMN area of HDC- $\Delta \gamma 2$ mouse brain. C, Histaminergic neurons labeled by Cre-dependent activation of the AAV-flex-rev- $\gamma 2$ F77-2A-Venus transgene, detected by immunocytochemistry with EGFP antisera. $\boldsymbol{D}$, Number of Venus-labeled neurons along the rostrocaudal axis of the posterior hypothalamus, detected by EGFP immunocytochemistry. $\boldsymbol{E}$, Spontaneous IPSCS recorded from histaminergic neurons in acute brain slices prepared from the posterior hypothalamus of C57BL/6J ( $\gamma 2 F 77), \gamma 2177^{10 x}$, and HDC- $\gamma 2 F 77$ mice before (black) and after $10 \mu \mathrm{M} \mathrm{zolpidem}$ (red) application. Traces represent peak-normalized, superimposed average waveforms. For the $557 \mathrm{BL} / 6 \mathrm{~J}(\gamma 2 \mathrm{F77})$ data, 87 events were averaged before zolpidem and 61 events were averaged after zolpidem. For the $\gamma 2177^{\text {lox }}$ data, 124 events were averaged before zolpidem and 167 events were averaged after zolpidem. For the HDC- $\gamma 2 F 77$ data, 59 events were averaged before zolpidem and 90 events were averaged after zolpidem. Graphs represent the mean weighted decay times before and after zolpidem application for the different groups of mice. ${ }^{* *} p=0.002$ (paired $t$ test).

2F77-2A-Venus, packaged into AAV capsids (Fig. 4A). This $A A V$-flex-rev- $\gamma 2 F 77-2 A$-Venus was bilaterally injected into the ventral TMN area of adult $H D C-\Delta \gamma 2 I 77$ mice to generate $H D C$ $\gamma 2 F 77$ mice (Fig. 4B). The flex switch in the AAV transgene ensured that $\gamma 2 \mathrm{~F} 77$ expression was restricted to Cre-positive neurons (Fig. 4A). These mice had bilateral expression of the $\gamma 2$ F77-2A-Venus transgene in their TMN area, confined to HDC neurons in the ventral parts of the TMN (Fig. $4 B, C$ ), in an $\sim 700$ $\mu \mathrm{m}$ anterior-to-posterior segment (Fig. $4 D$ ). The mean number of AAV-transduced neurons in HDC- $\gamma 2 F 77$ brains, as assessed by Venus expression, was compared with a count performed on a brain from an HDC-Cre $x$ Rosa-YFP reporter mouse cross. We 
A

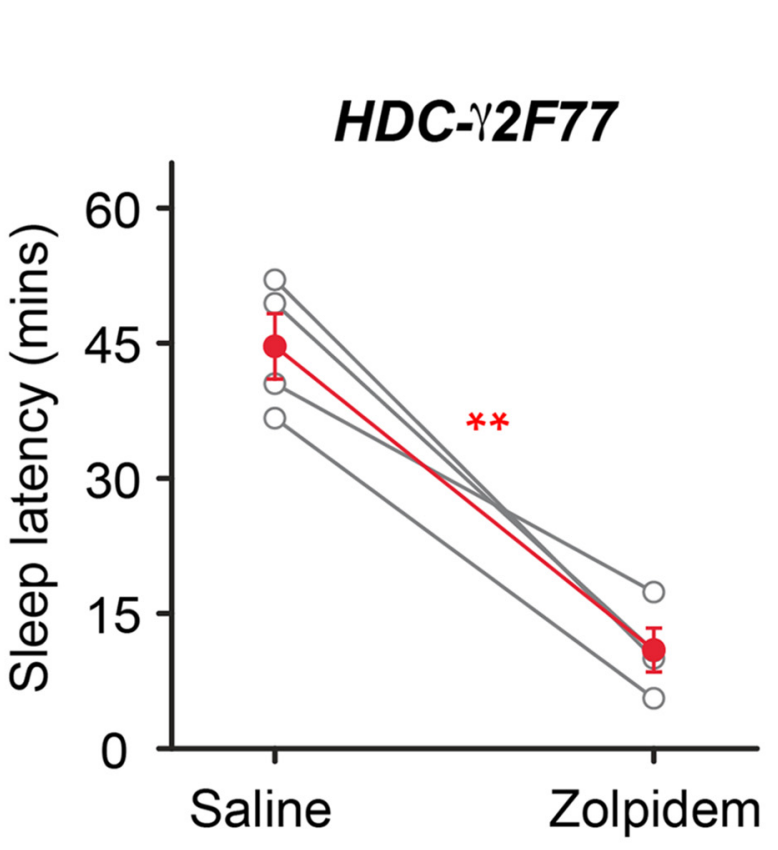

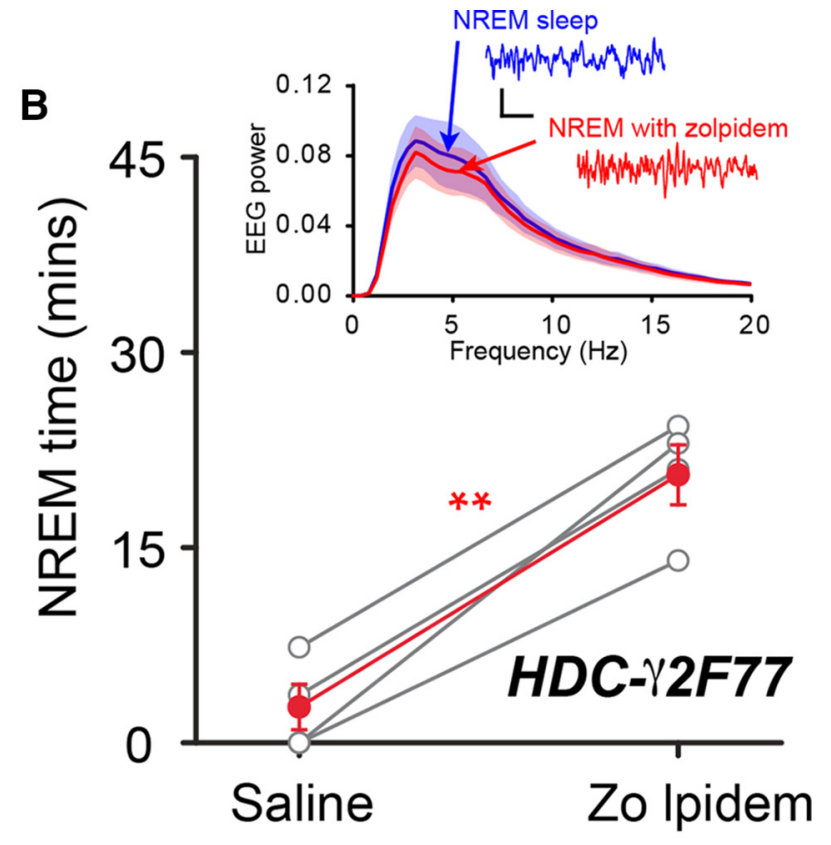

C

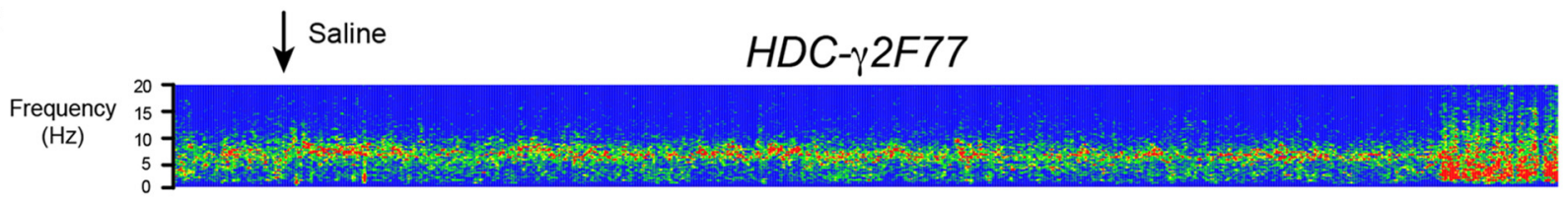

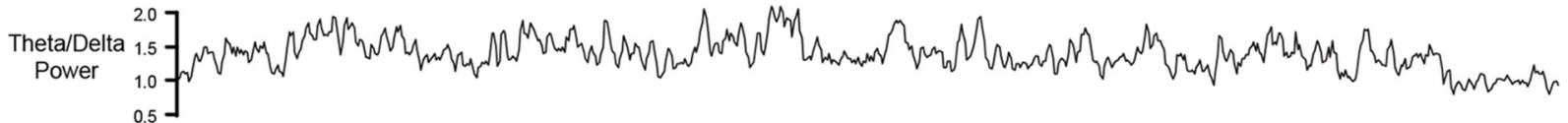

$\begin{array}{ll}\text { RMS EMG } & 2 \\ \text { (rel. units) } & 1 .]\end{array}$

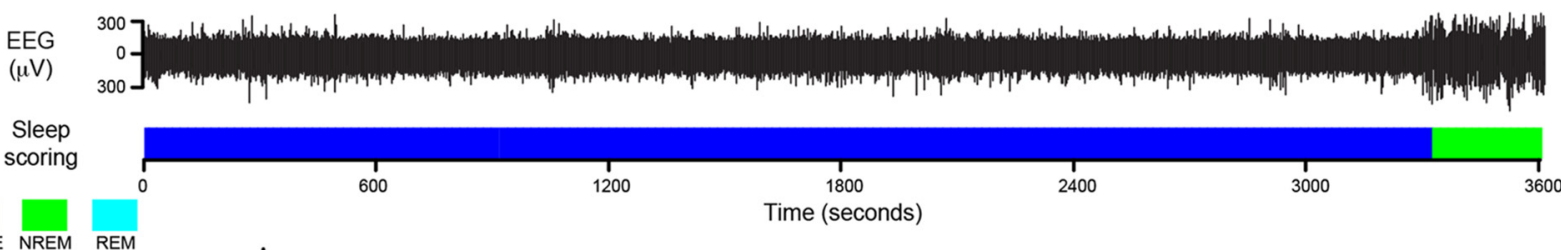

$\downarrow 5 \mathrm{mgs} / \mathrm{kg}$ Zolpidem

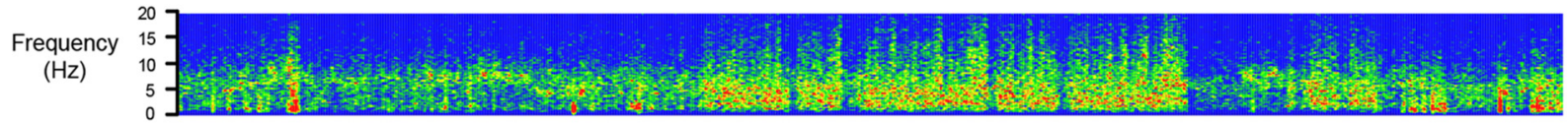

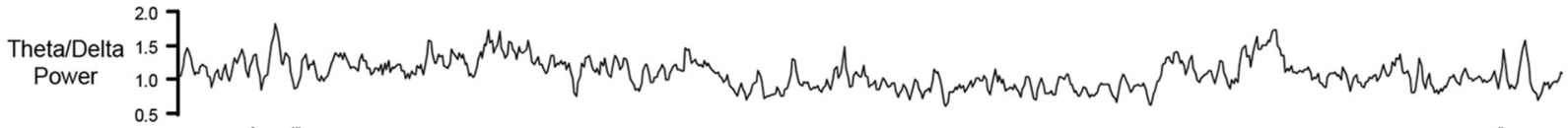

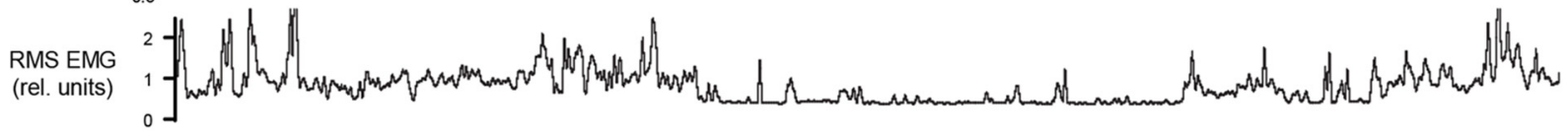

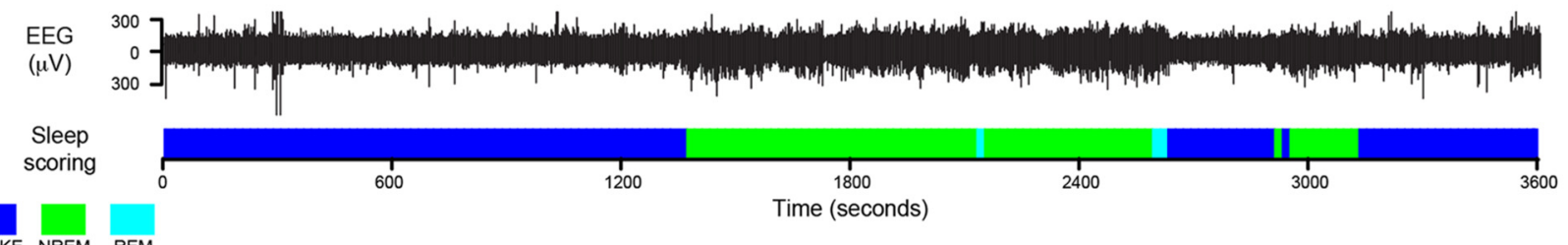


found HDC-Cre $x$ Rosa-YFP mice had $\sim 8000$ neurons in which the HDC promoter was active in the TMN area (data not shown). This could be an overestimate if some of the Rosa-YFP expression originates from the HDC-Cre gene turning on and off during development. In the adult HDC- $\gamma 2 F 77$ mice, where Venus expression can only be seen if the $H D C$-Cre gene is active in the adult, $\sim 7000$ Venus-positive cells could be detected. This number will be an underestimate because it cannot be expected that all histaminergic neurons in HDC- $\Delta \gamma 2 I 77$ mice would be transduced by the $A A V$-flex-rev- $\gamma 2 F 77-2 A-V e n u s$ virus (see below). On the other hand, counts of cells immunoreactive for histamine estimated that there were 2500-3500 such neurons in the mouse hypothalamus (Parmentier et al., 2002), and 3800 in the rat determined by staining with histidine decarboxylase antibodies (Ericson et al., 1987). Given the difference in sensitivity between the genetic and primary immunoreactive detection methods, our estimate of histaminergic neuronal number is approximately in the same range. The extent of AAV transduction in HDC- $\gamma 2 F 77$ mice was also ascertained by whole-cell voltage-clamp recordings in acute slices made from the posterior hypothalamus. In the ventral TMN region, we found that 10 of 16 neurons $(62.5 \%)$ had restored IPSCs that resembled IPSCs recorded from $C 57 B L / 6 J$ neurons (e.g., Fig. $4 E$ ). Of these 16 cells, the remaining 6 still had no IPSCs (data not shown). Presumably, these six neurons had not been transduced by $A A V$-flex-rev- $\gamma 2 F 77-2 A$-Venus virus and were still HDC- $\Delta \gamma 2 I 77$ knock-out cells (Zecharia et al., 2012). We confirmed that the HDC- $\gamma 2 F 77$ histaminergic neurons with rescued IPSCs also had restored zolpidem sensitivity. Zolpidem $(10 \mu \mathrm{M})$ applied to $C 57 B L / 6(\gamma 2 F 77)$ histaminergic cells slowed the IPSC decay by $48 \pm 8 \%$, from $30 \pm 3 \mathrm{~ms}$ (control) to $44 \pm 3$ ms (zolpidem) ( $n=5$ cells, paired $t$ test, $t_{(4)}=7.5, p=0.002$; Fig. $4 E$, left); by contrast, $10 \mu \mathrm{M}$ zolpidem applied to $\gamma 2 \mathrm{I} 77^{l o x}$ histaminergic neurons had no effect on the IPSC decay, being $\sim 23 \pm$ $4 \mathrm{~ms}$ (control) and $24 \pm 4 \mathrm{~ms}$ (zolpidem) $(n=5$ cells, paired $t$ test, $t_{(4)}=0.7, p=0.27$; Fig. $4 E$, middle). In contrast, $10 \mu \mathrm{M}$ zolpidem applied to HDC- $\gamma 2$ F77 TMN neurons slowed the IPSC decay by $\sim 46 \pm 7 \%$ from $24 \pm 3 \mathrm{~ms}$ (control) to $\sim 35 \pm 5 \mathrm{~ms}$ (zolpidem) $\left(n=6\right.$ cells, paired $t$ test, $t_{(5)}=5.7, p=0.002$; Fig. $4 E$, right), the same magnitude of response obtained by applying zolpidem to $C 57 B L / 6 J$ histaminergic neurons (Fig. $4 E$, left).

The baseline sleep-wake parameters of $H D C-\gamma 2 F 77$ mice did not differ from $\gamma 2 I 77^{l o x}$ or C57BL/6J mice (Table 1). We next examined whether administering zolpidem systemically to $H D C$ $\gamma 2$ F77 mice induced sleep (Fig. 5). Following a zolpidem (5 mg/ $\mathrm{kg}$, i.p.) injection, the sleep latency of HDC- $\gamma 2 F 77$ mice was significantly decreased by $\sim 75 \pm 6 \%$, from $45 \pm 4 \mathrm{~min}$ (saline) to $11 \pm 2$ min (zolpidem) $\left(n=4\right.$; paired $t$ test, $\left.t_{(3)}=8, p=0.004\right]$ (Fig. 5A). HDC- $\gamma 2 F 77$ mice spent significantly more time in NREM sleep $(21 \pm 2 \mathrm{~min})$ compared with mice injected with saline $(2.8 \pm 1.8 \mathrm{~min})\left(n=4\right.$; paired $t$ test, $t_{(3)}=9.5, p=0.002$; Fig. $5 B$ ). However, in the first $45 \mathrm{~min}$ after drug injection,

\footnotetext{
Figure 5. Selective potentiation of GABA inputs onto histaminergic neurons allows zolpidem to induce and maintain sleep. $\boldsymbol{A}$, Sleep latencies after saline and zolpidem $(5 \mathrm{mg} / \mathrm{kg})$ injections in HDC- $\gamma 2 F 77$ mice. ${ }^{* *} p=0.004$ (paired $t$ test). $\boldsymbol{B}$, Time spent in NREM sleep in the first 45 min after saline and zolpidem in HDC- $\gamma 2 F 77$ mice. ${ }^{* *} p=0.002$. $\boldsymbol{B}$, Inset, Normalized EEG power spectra from $H D C-\gamma 2 F 77$ mice following zolpidem ( $5 \mathrm{mg} / \mathrm{kg}$ i.p.; red) compared with their natural NREM sleep spectra (blue). Typical epochs of EEG trace are shown. C, EEG power spectra for $H D C-\gamma 2 F 77$ mice injected with saline or $5 \mathrm{mg} / \mathrm{kg}$ zolpidem. The spectra are aligned in register with the $\theta / \delta$ power ratio, the root mean square electromyogram (RMS EMG), the primary EEG, and the sleep scoring assignments (Wake, NREM, REM). Arrow indicates the time of saline or zolpidem injection.
}

zolpidem-injected $H D C-\gamma 2 F 77$ mice slept for approximately half as much time as zolpidem-injected $C 57 B L / 6 J$ mice. Furthermore, in contrast to zolpidem's effects in $C 57 B L / 6 \mathrm{~J}$ mice, zolpidem's ability to prolong sleep time in HDC- $\gamma 2 F 77$ did not persist beyond the first $45 \mathrm{~min}$ after injection. So we did not create the full effect of zolpidem $(5 \mathrm{mg} / \mathrm{kg})$ in $H D C-\gamma 2 F 77$ mice. In the sleep states induced by zolpidem in the HDC- $\gamma 2 F 77$ mice, EEG power in the zolpidem-induced sleep was not significantly reduced compared with that occurring in natural NREM sleep $(n=4$; paired $t$ test, $2-16 \mathrm{~Hz}$ inclusive, $t_{(3)}=1.84, p=0.16$; Fig. $5 B$, inset), which contrasts with the effect of zolpidem on EEG power in $C 57 B L / 6 J$ mice (Fig. $3 A$ ). Examples of the primary EEG recordings and sleep-scoring for saline- and zolpidem-injected $H D C$ $\gamma 2 F 77$ mice are shown in Figure $5 C$.

\section{The FC also can contribute to zolpidem-induced sleep induction but not maintenance}

In some circumstances, the FC could help initiate sleep (see Discussion). To test whether zolpidem might work partly through this route to induce sedation, we made the FC of $\gamma 2 \mathrm{I} 77^{\text {lox }}$ mice selectively zolpidem-sensitive by genetically swapping zolpidemsensitive $\gamma 2 \mathrm{~F} 77$ subunits into $\gamma 2 \mathrm{I} 77^{\mathrm{lox}}$ frontal cortical neurons, so generating $F C-\gamma 2 F 77$ mice (Fig. $6 A, B$ ). For this, we coinjected bilaterally a mixture of two AAVs into the FC: $A A V$-Cre- $2 A$ $\gamma 2 F 77$ and $A A V$-flex-rev-EGFP. This produced cotransduced neurons. The swap works as follows. From the $A A V$-Cre-2A$\gamma 2 F 77$ transgene, the Cre recombinase destroys production of functional $\gamma 2 \mathrm{I} 77$, and the zolpidem-sensitive $\gamma 2 \mathrm{~F} 77$ subunit replaces it; the second AAV expresses EGFP only if Cre recombinase is present, and thus marks neurons that have been transduced with $A A V$-Cre-2A- $\gamma 2 F 77$ (Fig. $6 A$ ). We visualized the transduced area by serial sectioning and then immunocytochemistry with GFP antisera (Fig. 6C,D). In all injections, the spread of transduced cells reached rostral almost to the olfactory bulb and caudal as far as the primary motor cortex (Fig. 6D). AAV-Cre- $2 A$ $\gamma 2 F 77$ transgene expression was found in both the frontal motor cortex and the prefrontal cortical areas (including prelimbic cortex, orbital areas, primary and secondary motor cortices). Maximally $20 \%$ of any given cortical area was transduced, mostly restricted to the deep layers of cortex, $\mathrm{V}$ and VI (Fig. 6C,D). To confirm that the $\gamma 2 \mathrm{I} 77$ to $\gamma 2 \mathrm{~F} 77$ swap had produced zolpidem sensitivity in pyramidal neurons of $F C-\gamma 2 F 77$ mice, we made acute slices of M1 and M2 frontal neocortex and performed whole-cell voltage-clamp recordings on pyramidal neurons from layers 5 and 6 . The neurons expressing the $A A V-C r e-2 A-\gamma 2 F 77$ transgene were identified by their primary EGFP signal. Zolpidem $(1 \mu \mathrm{M})$ slowed the decay of IPSCs by $63.5 \pm 14 \%$ in EGFPexpressing neurons, from $15.4 \pm 1.8 \mathrm{~ms}$ (control) to $24.5 \pm 2.2$ ms (zolpidem) $\left(n=6\right.$, paired $t$ test, $\left.t_{(5)}=6.4, p=0.001\right)($ Fig. $6 E$, right), which was similar to its effect on the IPSCs of $C 57 B L / 6$ pyramidal neurons ( $n=6$, paired $t$ test, $t_{(5)}=8.8, p=0.0003$; Fig. $6 E$, left); by contrast, the decay of IPSCs was unchanged by zolpidem $(13.2 \pm 2.2 \mathrm{~ms})$ in $\gamma 2 I 77^{\text {lox }}$ neocortical pyramidal neurons compared with control solution $(12.8 \pm 2.2 \mathrm{~ms})(n=5$, paired $t$ test, $t_{(4)}=1, p=0.4$; Fig. $6 E$, middle).

The baseline sleep-wake parameters of FC- $\gamma 2 F 77$ mice did not differ from $\gamma 2 I 77^{l o x}$ or $C 57 B L / 6 J$ mice (Table 1 ). We tested whether making FC neurons selectively zolpidem-sensitive was sufficient to produce a behavioral response in $\mathrm{FC}-\gamma 2 \mathrm{~F} 77$ mice (Fig. 7). We administered zolpidem ( $5 \mathrm{mg} / \mathrm{kg})$ to $F C-\gamma 2 F 77$ mice and found that this reduced latency to NREM sleep (Fig. 7A). $F C-\gamma 2 F 77$ mice had a $50 \pm 14 \%$ shorter latency to NREM sleep (zolpidem: $13 \pm 4 \mathrm{~min}$ ) compared with those injected with saline 
A

Mouse

$$
D \text { GABA }_{A} \gamma 2177 \text { Exon } 4-D
$$

AAV

$\square$ ITR CAG $>$ CRE 2A GABA ${ }_{A}$ 2F77 WPRE PA ITR

0 ITR CAG $D$ dE9 $\backslash$ WWPRE PA ITR

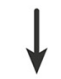

GABA $_{A} \gamma 2177$ Exon 4 deleted

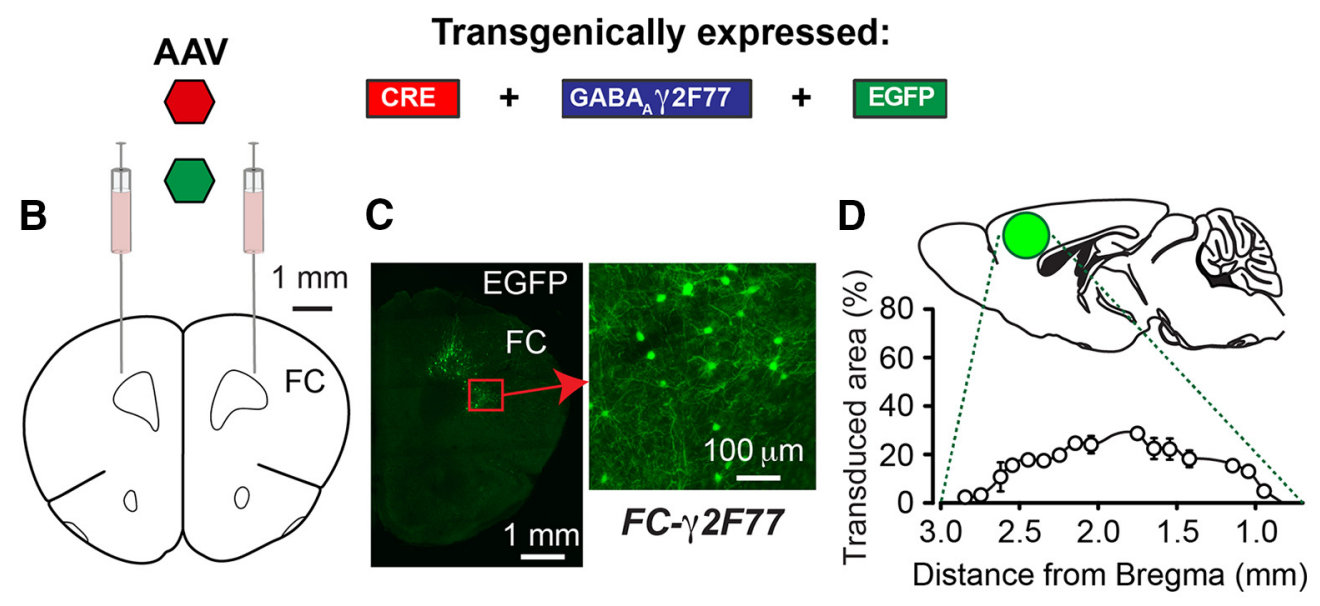

E

\section{C57BL/6}

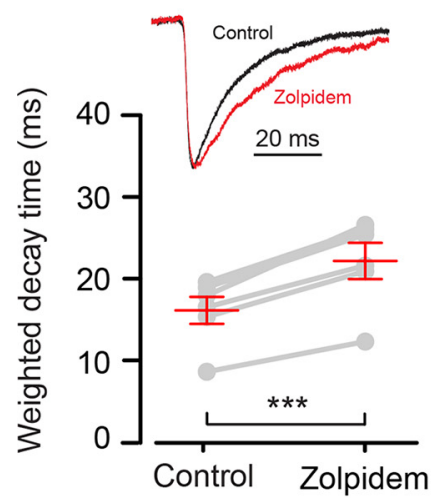

$\gamma 2177^{10 x}$

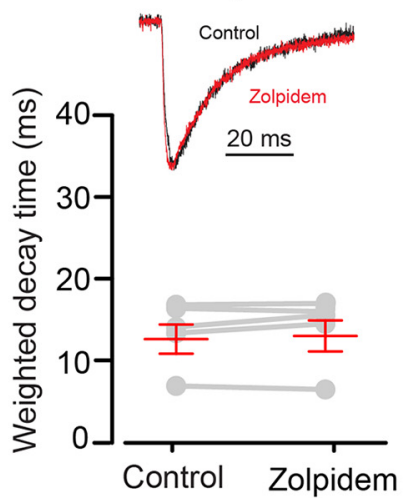

$F C-\gamma 2 F 77$

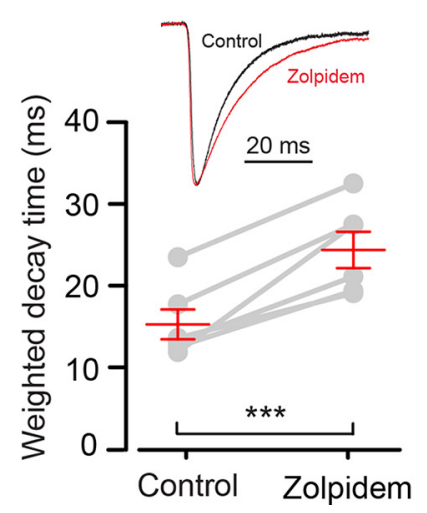

Figure 6. Making frontal cortical neurons selectively sensitive to zolpidem. A, Generating the $F\left(-\gamma 2 F 77\right.$ mice: the $\gamma 2177^{10 x}$ allele and the two AAVs, AAV-Cre-2A- $\gamma 2 F 77$ and AAV-flex-rev-EGFP, used to make the zolpidem-insensitive $\gamma 2177$ to zolpidem-sensitive $\gamma 2 \mathrm{~F} 77$ subunit swap in $\gamma 2177^{\text {lox }}$ mice in the FC. CMV, Cytomegalovirus enhancer/promoter; ITR, inverted terminal repeats; $\mathrm{pA}$, polyadenylation signal; WPRE, woodchuck post-transcriptional regulatory element. B, The two AAVs were mixed and coinjected into the FC of $\gamma 2177^{10 x}$ mice. $\boldsymbol{C}$, Overall expression of the AAV-Cre$2 A-\gamma 2 F 77$ transgene in pyramidal neurons (e.g., in layer $V$ shown here) was detected by EGFP immunocytochemistry. $\boldsymbol{D}$, Percentage area of transduced frontal neocortical sites along the rostrocaudal axis. E, Peak normalized spontaneous IPSCS recorded from cortical pyramidal neurons before (black) and after $1 \mu \mathrm{m}$ zolpidem (red) from (57BL/6J ( $\gamma 2 F 77), \gamma 2177^{10 x}$, and FC- $\gamma 2 F 77$ neurons. Traces are superimposed averages. To construct these, 251 events (before zolpidem) and 175 events (after zolpidem) were averaged for (57BL/6J neurons; 74 events (before zolpidem) and 71 events (after zolpidem) were averaged for $\gamma 2177^{\text {lox }}$ neurons; 247 events (before zolpidem) and 155 events (after zolpidem) were averaged for HDC- $\gamma 2 F 77$ neurons. Graphs represent mean weighted decay times of IPSCS before and after $1 \mu \mathrm{m}$ Zolpidem in $C 57 B L / 6 J\left(\gamma 2 F 77 ;{ }^{* * *} p=0.0003\right.$, paired $t$ test), $\gamma 2177^{\text {lox }}$ and $F\left(-\gamma 2 F 77\right.$ (layer 5/6) pyramidal neurons $\left({ }^{* * *} p=0.001\right.$, paired $t$ test).

$(30 \pm 6 \mathrm{~min})($ Fig. $7 A)\left(n=6\right.$; paired $t$ test, $\left.t_{(5)}=2.6, p=0.045\right)$. However, zolpidem did not significantly increase NREM time in $F C-\gamma 2 F 77$ mice compared with those injected with saline $(n=6$; paired $t$ test, $t_{(5)}=1.5, p=0.2$; Fig. $7 B$ ). The EEG power of this sleep following zolpidem administration in FC- $\gamma 2 F 77$ mice did not differ from natural NREM sleep $(n=6$, paired $t$ test, $2-16 \mathrm{~Hz}$ inclusive, $t_{(5)}=0.95, p=0.39$; Fig. $7 C$ ). Examples of the primary EEG recordings and sleep-scoring for saline- and zolpideminjected $F C-\gamma 2 F 77$ mice are shown in Figure 8.
The SC do not contribute to zolpidem's

sleep-inducing actions

Can zolpidem work in any brain area to induce NREM sleep? To test this, we looked at the SC (Fig. 9). The SCs are not associated with induction or maintenance of NREM sleep but do regulate eye movements and visual attention and also communicate with REM sleep-promoting areas. We made the SC of $\gamma 2 I 77^{l o x}$ mice selectively zolpidem-sensitive. $S C-\gamma 2 F 77$ mice were generated by bilaterally injecting $A A V-C r e-2 A-\gamma 2 F 77$ into the $S C$ of $\gamma 2 I 77^{l o x}$ 


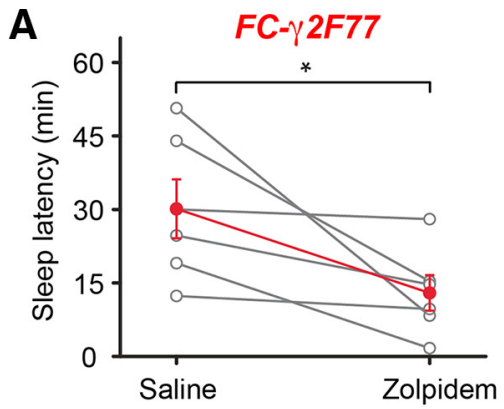

B
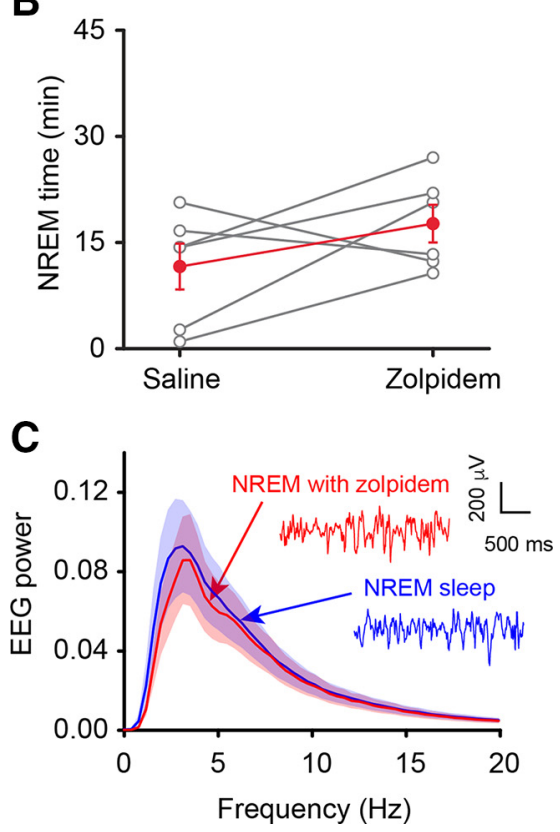

Figure 7. The FC contributes to zolpidem's ability to reduce sleep latency. $\boldsymbol{A}$, Sleep latencies. $B$, Sleep times in the first $45 \mathrm{~min}$ after either saline or zolpidem ( $5 \mathrm{mg} / \mathrm{kg})$ for $F(-\gamma 2 F 77$ mice. ${ }^{*} p=0.045$ (paired $t$ test). C, Normalized EEG power spectrum from $F(-\gamma 2 F 77$ mice following zolpidem (5 mg/kg i.p.; red) compared with their natural NREM sleep spectrum (blue).

mice (Fig. 9A,B). AAV-Cre-2A- $\gamma 2 F 77$ transgene expression, detected by staining with Cre recombinase antisera (Fig. 9C), was found throughout the layers of the SC. The baseline sleep-wake parameters of $S C-\gamma 2 F 77$ mice did not differ from $\gamma 2 I 77^{l o x}$ or C57BL/6J mice (Table 1). After zolpidem (5 mg/kg, i.p.) injection, the latency to NREM sleep ( $44 \pm 10 \mathrm{~min}$ ) of SC- $\gamma 2$ F77 mice did not differ from that following a saline injection (37 $\pm 2 \mathrm{~min})$ (Fig. $9 E ; n=4$; paired $t$ test, $t_{(3)}=0.8, p=0.48$ ). The NREM sleep time of $S C-\gamma 2 F 77$ mice was also not increased during the first 45 min after zolpidem administration compared with saline $(n=4$; paired $t$ test, $t_{(3)}=0.07, p=0.95$; Fig. $9 F$ ). Zolpidem did not change the proportion of REM sleep in $S C-\gamma 2 F 77$ mice in the first 45 min after injection.

\section{Discussion}

We have previously suggested that sedatives produce sleep by interacting with the NREM sleep-inducing circuitry, changing activity in the hypothalamic and brainstem circuits that globally govern arousal (Nelson et al., 2002; Franks, 2008; Lu et al., 2008; Zhang et al., 2015). We show here that this seems to be the case for zolpidem, too. By using a pharmacogenetic method that probes endogenous GABA tone, we found that selectively augmenting the active GABA input onto hypothalamic histamine neurons by systemic zolpidem administration decreased NREM sleep latency and enhanced sleep time but without reducing power in the EEG. As well as revealing a potential site for zolpidem's sleeppromoting actions in vivo, our pharmacogenetic findings support the hypothesis that the initiation of natural NREM sleep could arise by increased and sustained inhibition onto histaminergic neurons (Nitz and Siegel, 1996; Sherin et al., 1996, 1998).

\section{Clinical features of zolpidem mimicked in mice with brain regions selectively zolpidem-sensitive}

Positive $\mathrm{GABA}_{\mathrm{A}}$ receptor modulators are often good at inducing sleep (Lancel and Steiger, 1999; Winsky-Sommerer, 2009; Nutt and Stahl, 2010; Rye et al., 2012). Zolpidem's pharmacokinetics make it effective for treating insomnia: it maximally occupies its receptor sites minutes after entering the blood, causing sleep quickly, but its short plasma half-life limits "hangovers" (Benavides et al., 1988). In controlled clinical settings, zolpidem's main effect on people is to reduce sleep latency; but overall zolpidem performs no better than placebo in sleep maintenance, wake time after sleep onset, or number of awakenings (Greenblatt and Roth, 2012). By these measures, zolpidem's key clinical action, reduction of sleep latency, is mimicked by increasing inhibition onto histaminergic neurons. However, the NREM sleep induced by zolpidem in humans and wild-type rodents does not entirely resemble natural sleep because "zolpidem sleep" has diminished power in the EEG compared with natural NREM sleep for frequencies $>5 \mathrm{~Hz}$ in rodents (Kopp et al., 2004; Alexandre et al., 2008), and most frequencies in humans (Landolt et al., 2000). It is not clear whether this diminished EEG power is a good or bad feature of zolpidem-induced sleep. But in the HDC- $\gamma 2 F 77$ and $F C-\gamma 2 F 77$ mice, the power of zolpidem-evoked NREM sleep was the same as natural NREM sleep, so these "power-decreasing" effects of zolpidem must originate in other brain areas. This knowledge may be useful for designing sedatives that produce a more natural sleep.

\section{Zolpidem can induce NREM sleep by selectively inhibiting histaminergic neurons}

Despite having a 20 -fold higher affinity at $\alpha 1 \beta \gamma 2$-containing $\mathrm{GABA}_{\mathrm{A}}$ receptors (Pritchett and Seeburg, 1990), which are the most widely expressed and abundant type of $\mathrm{GABA}_{\mathrm{A}}$ receptors in the brain (Pritchett et al., 1989; Wisden et al., 1992; McKernan and Whiting, 1996), zolpidem (5 mg/kg) induces sleep through the $\alpha 2 \beta \gamma 2$ and/or $\alpha 3 \beta \gamma 2 \mathrm{GABA}_{\mathrm{A}}$ receptors (Kopp et al., 2004). The $\alpha 1$-containing receptors are, instead, responsible for the decrease in EEG power across most frequencies $>5 \mathrm{~Hz}$ in zolpidemevoked sleep (Kopp et al., 2004). We might also expect that zolpidem's effects, such as sleep, result from additive slowing of IPSCs on cell types with $\alpha 2$ and/or $\alpha 3$ subunits throughout the brain. But this is not the case. Prolonging IPSCs on just histaminergic neurons is enough to induce and maintain sleep, although not to the full extent generated by zolpidem in wild-type C57BL/6 J mice. Zolpidem is probably effective at histamine neurons because of their hub-like nature and their ability to promote arousal and wakefulness (Haas and Panula, 2003). Although there are relatively few histamine neurons, between 3000 and 7000 in the mouse, their axons ascend and descend from the TMN, coursing throughout the brain, coreleasing histamine and GABA to give balanced arousal (Wada et al., 1991; Haas and Panula, 2003; Yu et al., 2015). Thus, acutely inhibiting the "histamine hub" by zolpidem will cause histamine levels to fall throughout the brain and sleep to ensue. This fits with previous pharmacological data that infusing GABA agonists into the TMN area induces sleep (Lin et al., 1989; Nitz and Siegel, 1996), and 


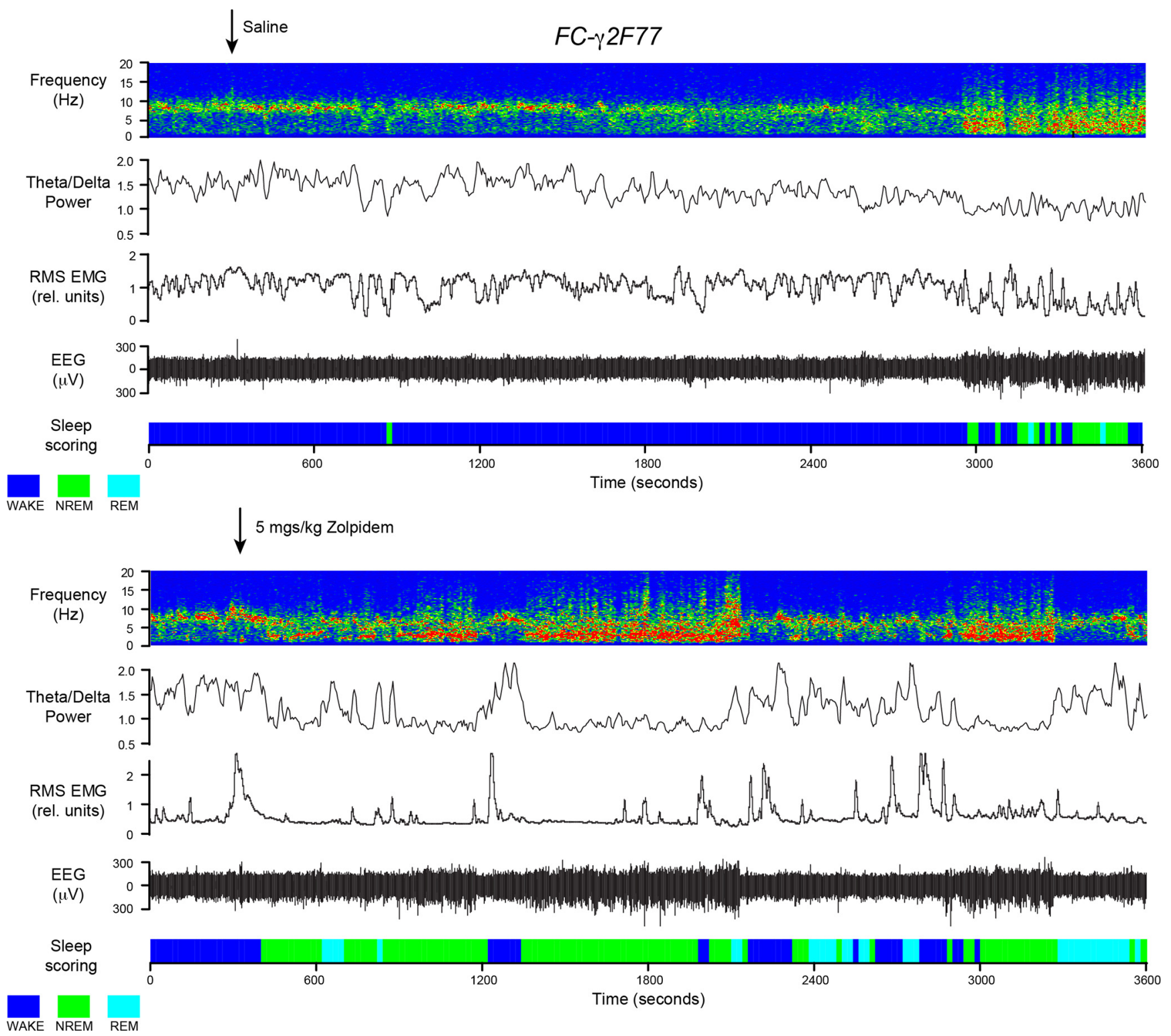

Figure 8. EEG power spectra and sleep scoring for zolpidem-induced sleep in $F C-\gamma 2 F 77$ mice. EEG power spectra for $F C-\gamma 2 F 77$ mice injected with saline or $5 \mathrm{mg} / \mathrm{kg}$ zolpidem. The spectra are aligned in register with the $\theta / \delta$ power ratio, the root mean square electromyogram (RMS EMG), the primary EEG, and the sleep scoring assignments (Wake, NREM, REM). Arrow indicates the time of saline or zolpidem injection.

that GABA/galanin neurons in the lateral preoptic neurons, which send axons to the TMN, increase their activity during sleep (Sherin et al., 1996, 1998). Histaminergic neurons principally express $\alpha 1 \beta 3 \gamma 2$ and $\alpha 2 \beta 3 \gamma 2 \mathrm{GABA}_{\mathrm{A}}$ receptors (Fritschy and Mohler, 1995; Sergeeva et al., 2002; Zecharia et al., 2009, 2012; May et al., 2013). Thus, these $\alpha 2$-containing $\mathrm{GABA}_{\mathrm{A}}$ receptors on the histaminergic neurons are likely candidates for a part of zolpidem's sleep-inducing actions in vivo. The $\alpha 1$-containing $\mathrm{GABA}_{\mathrm{A}}$ receptors that cause zolpidem to reduce EEG power must be on other types of neurons elsewhere.

\section{Zolpidem can initiate sleep top-down from the FC}

We found that zolpidem can act in the frontal neocortex to reduce sleep latency, although the effect was not as large as for the histaminergic neurons, and sleep time was also not increased. Other data also link the frontal and preFC and behavioral sleep: sleep can initiate top-down if the $\mathrm{FC}$ is stimulated at $4 \mathrm{~Hz}$ (Penaloza-Rojas et al., 1964; Lineberry and Siegel, 1971); slow waves initiate in frontal neocortex (Massimini et al., 2004; Vyazovskiy et al., 2009); and in human aging, atrophy of the medial prefrontal cortex correlates with disrupted NREM slow waves (Mander et al., 2013).

\section{Pharmacogenetic manipulation of GABA inputs versus receptor knock-outs, acute versus chronic}

There are several caveats to consider when interpreting our results. The first point is that acute inhibition of one area in the brain could affect circuit dynamics in other areas (Otchy et al., 2015). The brain's dense interconnectivity could cloud, rather than reveal, the function of the inhibited region and so "transient circuit manipulations may have their own interpretive difficulties" (Otchy et al., 2015). This could indicate that zolpidem does not normally induce sleep by enhancing inhibition on histamine neurons but only does so in this particular artificial situation whereby the histamine neurons are made uniquely sensitive to zolpidem in the HDC- $\gamma 2 F 77$ mice. The second point is that dif- 
A

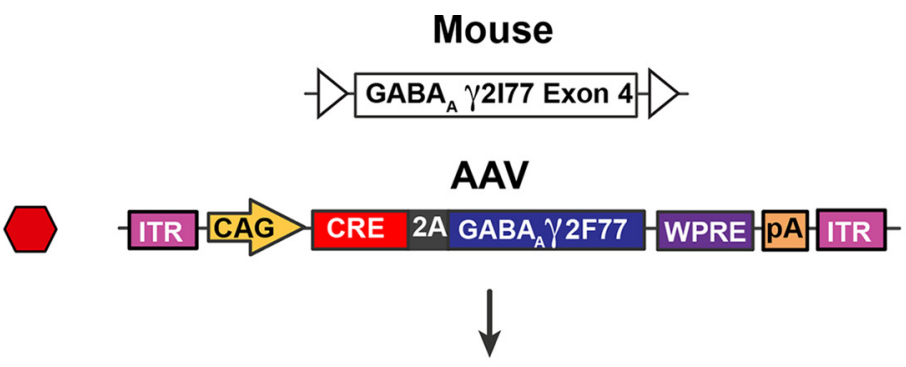

GABA $_{A} \gamma 2177$ Exon 4 deleted

Transgenically expressed:

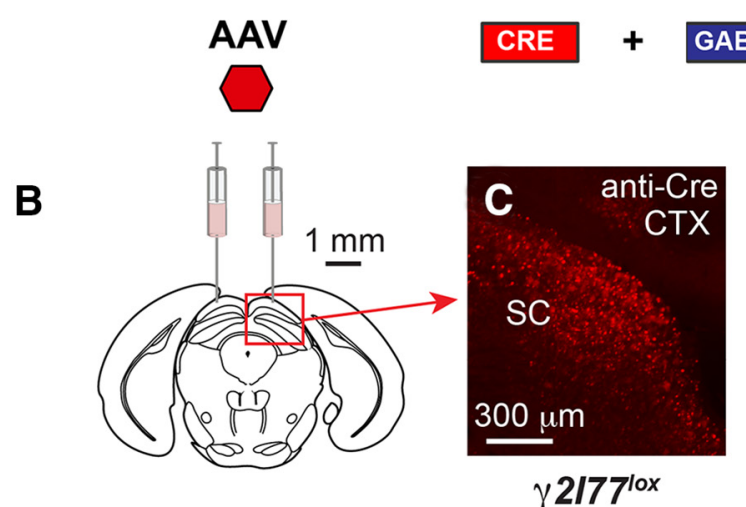

E

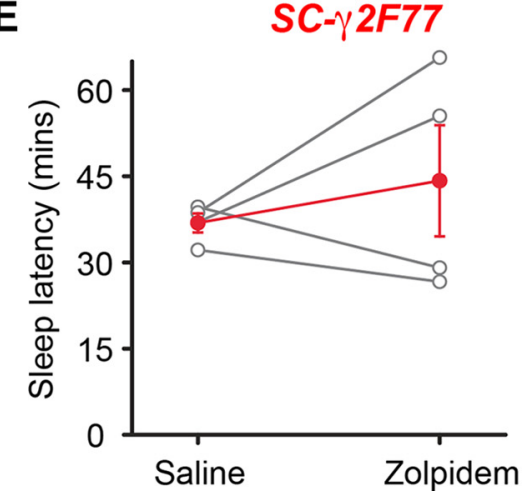

$\mathbf{F}$

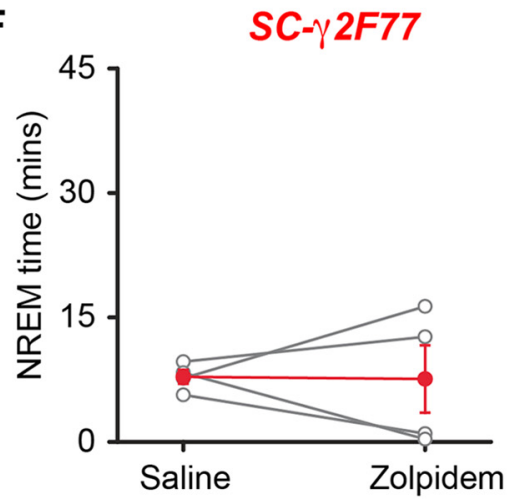

Figure 9. The SC do not contribute to zolpidem-induced sleep. $A$, Generating the SC- $\gamma 2 F 77$ mice: the $A A V-C r e-2 A-\gamma 2 F 77$ transgene used to make the zolpidem-insensitive $\gamma 2177$ to zolpidemsensitive $\gamma 2 F 77$ subunit swap in $\gamma 2177^{\text {lox }}$ mice. CTX, Neocortex; CMV, cytomegalovirus enhancer/promoter; ITR, inverted terminal repeats; pA, polyadenylation signal; WPRE, woodchuck posttranscriptional regulatory element. $B$, Bilateral $A A V-C r e-2 A-\gamma 2 F 77$ microinjection into the $S C$ of $\gamma 2177^{10 x}$ mouse brain to generate $S C-\gamma 2 F 77$ mice. C, Detection of $A A V$ - $C r e-2 A-\gamma 2 F 77$ transgene expression in the SC by anti-Cre immunohistochemistry. CTX, Neocortex. D, Percentage area of AAV-transduced SC along the rostrocaudal axis, deduced by counting Cre-positive cells. $\boldsymbol{E}$, Sleep latency. $\boldsymbol{F}$, Sleep time after saline and zolpidem (5 mg/kg) injections in SC- $\gamma 2 F 77$ mice.

ferent results are often produced by chronic or acute ablations (Wisden et al., 2009; Otchy et al., 2015). Genetic ablation of the $\mathrm{GABA}_{\mathrm{A}}$ receptor $\gamma 2$ subunit from histaminergic neurons did not affect normal sleep over a $24 \mathrm{~h}$ period, although it did produce the more subtle effect of preventing the mice settling down and going to sleep in a new environment; in other words, removing synaptic $\mathrm{GABA}_{\mathrm{A}}$ receptors from histaminergic neurons lengthened the latency to NREM sleep (Zecharia et al., 2012), and this fits with our new data that, going in the opposite direction, enhancing IPSCs with zolpidem on these neurons shortens the latency to NREM sleep. Nevertheless, it remains remarkable that fast GABA input to the histamine neurons is dispensable for controlling the basic sleep-wake cycle. Similar to our results on histamine neurons, we found that chronic ablation versus acute pharmacoge- netic modulation of GABA inputs on cerebellar Purkinje neurons also produced different results: mice with zolpidem-sensitive $\mathrm{GABA}_{\mathrm{A}}$ receptors selectively expressed in Purkinje neurons had acute ataxia after being given zolpidem, and so we concluded that ongoing GABA input onto Purkinje cells modulates motor control (Wulff et al., 2007; Wisden et al., 2009); by contrast, knocking out the $\gamma 2$ subunit selectively and permanently from Purkinje cells, and the consequent removal of fast synaptic responses to GABA, did not produce overt ataxia, but only a subtle deficit in limb coordination (Vinueza Veloz et al., 2015). To explain the large difference in behavioral phenotype produced by acute zolpidem modulation of Purkinje cells and chronic ablation of fast inhibitory input, we hypothesized that the cerebellar circuitry with chronically removed synaptic GABA input on Purkinje cells 
had undergone adaptation (Wulff et al., 2007; Wisden et al., 2009). We think the weak phenotypes produced by $\gamma 2$ subunit ablation from Purkinje cells and histaminergic cells, and the contrasting strong phenotypes obtained by acute manipulation with zolpidem are analogous: the pharmacogenetic "zolpidem method" unmasks the acute role for GABA in modulating histaminergic neurons, whereas $H D C-\Delta \gamma 2$ mice have undergone compensatory changes. Acute zolpidem manipulation in HDCy2F77 mice produces the "true" result.

In conclusion, zolpidem has rather subtle effects on synaptic IPSCs. Typically, it prolongs them by $\sim 50 \%$. We might have expected that zolpidem induces sleep by potentiating IPSCs everywhere in the brain; the net effect would be behavioral sleep. But instead we have shown that zolpidem can induce sleep by strengthening GABA signaling on just one cell type (histamine neurons). Normally, the NREM sleep induced by zolpidem does not resemble natural sleep; the drug produces a lower power in most frequencies of the EEG during NREM sleep. But via histamine neurons, zolpidem can induce sleep without reducing the EEG power of the sleep. This knowledge could help design drugs that induce a more natural sleep.

\section{References}

Alexandre C, Dordal A, Aixendri R, Guzman A, Hamon M, Adrien J (2008) Sleep-stabilizing effects of E-6199, compared to zopiclone, zolpidem and THIP in mice. Sleep 31:259-270. Medline

Anaclet C, Zhang M, Zhao C, Buda C, Seugnet L, Lin JS (2012) Effects of GF-015535-00, a novel alphal GABA A receptor ligand, on the sleepwake cycle in mice, with reference to zolpidem. Sleep 35:103-111. CrossRef Medline

Anisimov VN, Herbst JA, Abramchuk AN, Latanov AV, Hahnloser RH, Vyssotski AL (2014) Reconstruction of vocal interactions in a group of small songbirds. Nat Methods 11:1135-1137. CrossRef Medline

Arbilla S, Depoortere H, George P, Langer SZ (1985) Pharmacological profile of the imidazopyridine zolpidem at benzodiazepine receptors and electrocorticogram in rats. Naunyn Schmiedebergs Arch Pharmacol 330: 248-251. CrossRef Medline

Atasoy D, Aponte Y, Su HH, Sternson SM (2008) A FLEX switch targets Channelrhodopsin-2 to multiple cell types for imaging and long-range circuit mapping. J Neurosci 28:7025-7030. CrossRef Medline

Benavides J, Peny B, Dubois A, Perrault G, Morel E, Zivkovic B, Scatton B (1988) In vivo interaction of zolpidem with central benzodiazepine (BZD) binding sites (as labeled by [ $\left.{ }^{3} \mathrm{H}\right] \mathrm{Ro}$ 15-1788) in the mouse brain: preferential affinity of zolpidem for the omega 1 (BZD1) subtype. J Pharmacol Exp Ther 245:1033-1041. Medline

Buhr A, Baur R, Sigel E (1997) Subtle changes in residue 77 of the gamma subunit of alphalbeta2gamma2 GABAA receptors drastically alter the affinity for ligands of the benzodiazepine binding site. J Biol Chem 272: 11799-11804. CrossRef Medline

Cope DW, Wulff P, Oberto A, Aller MI, Capogna M, Ferraguti F, Halbsguth C, Hoeger H, Jolin HE, Jones A, McKenzie AN, Ogris W, Poeltl A, Sinkkonen ST, Vekovischeva OY, Korpi ER, Sieghart W, Sigel E, Somogyi P, Wisden W (2004) Abolition of zolpidem sensitivity in mice with a point mutation in the GABAA receptor gamma2 subunit. Neuropharmacology 47:17-34. CrossRef Medline

Costa-Miserachs D, Portell-Cortés I, Torras-Garcia M, Morgado-Bernal I (2003) Automated sleep staging in rat with a standard spreadsheet. J Neurosci Methods 130:93-101. CrossRef Medline

Crestani F, Martin JR, Möhler H, Rudolph U (2000) Mechanism of action of the hypnotic zolpidem in vivo. Br J Pharmacol 131:1251-1254. CrossRef Medline

Duncan GE, Breese GR, Criswell HE, McCown TJ, Herbert JS, Devaud LL, Morrow AL (1995) Distribution of $\left[{ }^{3} \mathrm{H}\right]$ zolpidem binding sites in relation to messenger RNA encoding the alpha 1 , beta 2 and gamma 2 subunits of GABAA receptors in rat brain. Neuroscience 64:1113-1128. CrossRef Medline

Ericson H, Watanabe T, Köhler C (1987) Morphological analysis of the tuberomammillary nucleus in the rat brain: delineation of subgroups with antibody against L-histidine decarboxylase as a marker. J Comp Neurol 263:1-24. CrossRef Medline

Franks NP (2008) General anaesthesia: from molecular targets to neuronal pathways of sleep and arousal. Nat Rev Neurosci 9:370-386. CrossRef Medline

Fritschy JM, Mohler H (1995) GABAA-receptor heterogeneity in the adult rat brain: differential regional and cellular distribution of seven major subunits. J Comp Neurol 359:154-194. CrossRef Medline

Gottesmann C, Gandolfo G, Arnaud C, Gauthier P (1998) The intermediate stage and paradoxical sleep in the rat: influence of three generations of hypnotics. Eur J Neurosci 10:409-414. CrossRef Medline

Greenblatt DJ, Roth T (2012) Zolpidem for insomnia. Expert Opin Pharmacother 13:879-893. CrossRef Medline

Günther U, Benson J, Benke D, Fritschy JM, Reyes G, Knoflach F, Crestani F, Aguzzi A, Arigoni M, Lang Y, et al. (1995) Benzodiazepine-insensitive mice generated by targeted disruption of the gamma 2 subunit gene of gamma-aminobutyric acid type A receptors. Proc Natl Acad Sci U S A 92:7749-7753. CrossRef Medline

Haas H, Panula P (2003) The role of histamine and the tuberomamillary nucleus in the nervous system. Nat Rev Neurosci 4:121-130. CrossRef Medline

Hörtnagl H, Tasan RO, Wieselthaler A, Kirchmair E, Sieghart W, Sperk G (2013) Patterns of mRNA and protein expression for 12 GABAA receptor subunits in the mouse brain. Neuroscience 236:345-372. CrossRef Medline

Janusonis S (2009) Comparing two small samples with an unstable, treatment-independent baseline. J Neurosci Methods 179:173-178. CrossRef Medline

Klugmann M, Symes CW, Leichtlein CB, Klaussner BK, Dunning J, Fong D, Young D, During MJ (2005) AAV-mediated hippocampal expression of short and long Homer 1 proteins differentially affect cognition and seizure activity in adult rats. Mol Cell Neurosci 28:347-360. CrossRef Medline

Kopp C, Rudolph U, Tobler I (2004) Sleep EEG changes after zolpidem in mice. Neuroreport 15:2299-2302. CrossRef Medline

Krashes MJ, Koda S, Ye C, Rogan SC, Adams AC, Cusher DS, Maratos-Flier E, Roth BL, Lowell BB (2011) Rapid, reversible activation of AgRP neurons drives feeding behavior in mice. J Clin Invest 121:1424-1428. CrossRef Medline

Lancel M, Steiger A (1999) Sleep and its modulation by drugs that affect GABA(A) receptor function. Angew Chem Int Ed Engl 38:2852-2864. CrossRef Medline

Landolt HP, Finelli LA, Roth C, Buck A, Achermann P, Borbély AA (2000) Zolpidem and sleep deprivation: different effect on EEG power spectra. J Sleep Res 9:175-183. CrossRef Medline

Leppä E, Linden AM, Rabe H, Vekovischeva OY, Wulff P, Lüddens H, Wisden W, Korpi ER (2011) Actions of two GABAA receptor benzodiazepinesite ligands that are mediated via non-gamma2-dependent modulation. Eur J Pharmacol 666:111-121. CrossRef Medline

Lin JS, Sakai K, Vanni-Mercier G, Jouvet M (1989) A critical role of the posterior hypothalamus in the mechanisms of wakefulness determined by microinjection of muscimol in freely moving cats. Brain Res 479:225-240. CrossRef Medline

Lineberry CG, Siegel J (1971) EEG synchronization, behavioral inhibition, and mesencephalic unit effects produced by stimulation of orbital cortex, basal forebrain and caudate nucleus. Brain Res 34:143-161. CrossRef Medline

Lu J, Nelson LE, Franks N, Maze M, Chamberlin NL, Saper CB (2008) Role of endogenous sleep-wake and analgesic systems in anesthesia. J Comp Neurol 508:648-662. CrossRef Medline

Mander BA, Rao V, Lu B, Saletin JM, Lindquist JR, Ancoli-Israel S, Jagust W, Walker MP (2013) Prefrontal atrophy, disrupted NREM slow waves and impaired hippocampal-dependent memory in aging. Nat Neurosci 16: 357-364. CrossRef Medline

Massimini M, Huber R, Ferrarelli F, Hill S, Tononi G (2004) The sleep slow oscillation as a traveling wave. J Neurosci 24:6862-6870. CrossRef Medline

May AC, Fleischer W, Kletke O, Haas HL, Sergeeva OA (2013) Benzodiazepine-site pharmacology on GABAA receptors in histaminergic neurons. Br J Pharmacol 170:222-232. CrossRef Medline

McKernan RM, Whiting PJ (1996) Which GABAA-receptor subtypes really occur in the brain? Trends Neurosci 19:139-143. CrossRef Medline 
Mignot E (2013) Physiology: the perfect hypnotic? Science 340:36-38. CrossRef Medline

Nelson LE, Guo TZ, Lu J, Saper CB, Franks NP, Maze M (2002) The sedative component of anesthesia is mediated by GABA(A) receptors in an endogenous sleep pathway. Nat Neurosci 5:979-984. CrossRef Medline

Niddam R, Dubois A, Scatton B, Arbilla S, Langer SZ (1987) Autoradiographic localization of $\left[{ }^{3} \mathrm{H}\right]$ zolpidem binding sites in the rat CNS: comparison with the distribution of $\left[{ }^{3} \mathrm{H}\right]$ flunitrazepam binding sites. J Neurochem 49:890-899. CrossRef Medline

Nitz D, Siegel JM (1996) GABA release in posterior hypothalamus across sleep-wake cycle. Am J Physiol 271:R1707-R1712. Medline

Nutt DJ, Stahl SM (2010) Searching for perfect sleep: the continuing evolution of GABAA receptor modulators as hypnotics. J Psychopharmacol 24:1601-1612. CrossRef Medline

Otchy TM, Wolff SB, Rhee JY, Pehlevan C, Kawai R, Kempf A, Gobes SM, Ölveczky BP (2015) Acute off-target effects of neural circuit manipulations. Nature 528:358-363. CrossRef Medline

Parmentier R, Ohtsu H, Djebbara-Hannas Z, Valatx JL, Watanabe T, Lin JS (2002) Anatomical, physiological, and pharmacological characteristics of histidine decarboxylase knock-out mice: evidence for the role of brain histamine in behavioral and sleep-wake control. J Neurosci 22:76957711. Medline

Penaloza-Rojas JH, Eltherman M, Olmos N (1964) Sleep induced by cortical stimulation. Exp Neurol 10:140-147. CrossRef Medline

Pritchett DB, Seeburg PH (1990) Gamma-aminobutyric acidA receptor alpha 5-subunit creates novel type II benzodiazepine receptor pharmacology. J Neurochem 54:1802-1804. CrossRef Medline

Pritchett DB, Sontheimer H, Shivers BD, Ymer S, Kettenmann H, Schofield PR, Seeburg PH (1989) Importance of a novel GABAA receptor subunit for benzodiazepine pharmacology. Nature 338:582-585. CrossRef Medline

RihelJ, Schier AF (2013) Sites of action of sleep and wake drugs: insights from model organisms. Curr Opin Neurobiol 23:831-840. CrossRef Medline

Rovó Z, Mátyás F, Barthó P, Slézia A, Lecci S, Pellegrini C, Astori S, Dávid C, Hangya B, Lüthi A, Acsády L (2014) Phasic, nonsynaptic GABA-A receptor-mediated inhibition entrains thalamocortical oscillations. J Neurosci 34:7137-7147. CrossRef Medline

Rye DB, Bliwise DL, Parker K, Trotti LM, Saini P, Fairley J, Freeman A, Garcia PS, Owens MJ, Ritchie JC, Jenkins A (2012) Modulation of vigilance in the primary hypersomnias by endogenous enhancement of GABAA receptors. Sci Transl Med 4:161ra151. CrossRef Medline

Sergeeva OA, Eriksson KS, Sharonova IN, Vorobjev VS, Haas HL (2002) GABA(A) receptor heterogeneity in histaminergic neurons. Eur J Neurosci 16:1472-1482. CrossRef Medline

Sherin JE, Shiromani PJ, McCarley RW, Saper CB (1996) Activation of ventrolateral preoptic neurons during sleep. Science 271:216-219. CrossRef Medline

Sherin JE, Elmquist JK, Torrealba F, Saper CB (1998) Innervation of histaminergic tuberomammillary neurons by GABAergic and galaninergic neurons in the ventrolateral preoptic nucleus of the rat. J Neurosci 18: 4705-4721. Medline

Sieghart W (2012) Unravelling the role of GABAA receptor subtypes in distinct neurons and behaviour. J Physiol 590:2181-2182. CrossRef Medline

Stevens DR, Eriksson KS, Brown RE, Haas HL (2001) The mechanism of spontaneous firing in histamine neurons. Behav Brain Res 124:105-112. CrossRef Medline

Sumegi M, Fukazawa Y, Matsui K, Lorincz A, Eyre MD, Nusser Z, Shigemoto R (2012) Virus-mediated swapping of zolpidem-insensitive with zolpidem-sensitive GABA(A) receptors in cortical pyramidal cells. J Physiol 590:1517-1534. CrossRef Medline

Vinueza Veloz MF, Zhou K, Bosman LW, Potters JW, Negrello M, Seepers RM, Strydis C, Koekkoek SK, De Zeeuw CI (2015) Cerebellar control of gait and interlimb coordination. Brain Struct Funct 220:3513-3536. CrossRef Medline
Vyazovskiy VV, Faraguna U, Cirelli C, Tononi G (2009) Triggering slow waves during NREM sleep in the rat by intracortical electrical stimulation: effects of sleep/wake history and background activity. J Neurophysiol 101:1921-1931. CrossRef Medline

Wada H, Inagaki N, Yamatodani A, Watanabe T (1991) Is the histaminergic neuron system a regulatory center for whole-brain activity? Trends Neurosci 14:415-418. CrossRef Medline

Wafford KA, Ebert B (2008) Emerging anti-insomnia drugs: tackling sleeplessness and the quality of wake time. Nat Rev Drug Discov 7:530-540. CrossRef Medline

Wingrove PB, Thompson SA, Wafford KA, Whiting PJ (1997) Key amino acids in the gamma subunit of the gamma-aminobutyric acidA receptor that determine ligand binding and modulation at the benzodiazepine site. Mol Pharmacol 52:874-881. CrossRef Medline

Winsky-Sommerer R (2009) Role of GABAA receptors in the physiology and pharmacology of sleep. Eur J Neurosci 29:1779-1794. CrossRef Medline

Wisden W, Morris BJ, Darlison MG, Hunt SP, Barnard EA (1988) Distinct GABAA receptor alpha subunit mRNAs show differential patterns of expression in bovine brain. Neuron 1:937-947. CrossRef Medline

Wisden W, Laurie DJ, Monyer H, Seeburg PH (1992) The distribution of 13 GABAA receptor subunit mRNAs in the rat brain: I. Telencephalon, diencephalon, mesencephalon. J Neurosci 12:1040-1062. Medline

Wisden W, Murray AJ, McClure C, Wulff P (2009) Studying cerebellar circuits by remote control of selected neuronal types with GABA(A) receptors. Front Mol Neurosci 2:29. CrossRef Medline

Wulff P, Goetz T, Leppä E, Linden AM, Renzi M, Swinny JD, Vekovischeva OY, Sieghart W, Somogyi P, Korpi ER, Farrant M, Wisden W (2007) From synapse to behavior: rapid modulation of defined neuronal types with engineered GABAA receptors. Nat Neurosci 10:923-929. CrossRef Medline

Wulff P, Ponomarenko AA, Bartos M, Korotkova TM, Fuchs EC, Bähner F, Both M, Tort AB, Kopell NJ, Wisden W, Monyer H (2009a) Hippocampal $\theta$ rhythm and its coupling with gamma oscillations require fast inhibition onto parvalbumin-positive interneurons. Proc Natl Acad Sci U S A 106:3561-3566. CrossRef Medline

Wulff P, Schonewille M, Renzi M, Viltono L, Sassoè-Pognetto M, Badura A, Gao Z, Hoebeek FE, van Dorp S, Wisden W, Farrant M, De Zeeuw CI (2009b) Synaptic inhibition of Purkinje cells mediates consolidation of vestibulo-cerebellar motor learning. Nat Neurosci 12:10421049. CrossRef Medline

Xu Q, Xu XH, Qu WM, Lazarus M, Urade Y, Huang ZL (2014) A mouse model mimicking human first night effect for the evaluation of hypnotics. Pharmacol Biochem Behav 116:129-136. CrossRef Medline

Yu X, Ye Z, Houston CM, Zecharia AY, Ma Y, Zhang Z, Uygun DS, Parker S, Vyssotski AL, Yustos R, Franks NP, Brickley SG, Wisden W (2015) Wakefulness is governed by GABA and histamine cotransmission. Neuron 87:164-178. CrossRef Medline

Zecharia AY, Nelson LE, Gent TC, Schumacher M, Jurd R, Rudolph U, Brickley SG, Maze M, Franks NP (2009) The involvement of hypothalamic sleep pathways in general anesthesia: testing the hypothesis using the GABAA receptor beta3N265M knock-in mouse. J Neurosci 29:21772187. CrossRef Medline

Zecharia AY, Yu X, Götz T, Ye Z, Carr DR, Wulff P, Bettler B, Vyssotski AL, Brickley SG, Franks NP, Wisden W (2012) GABAergic inhibition of histaminergic neurons regulates active waking but not the sleep-wake switch or propofol-induced loss of consciousness. J Neurosci 32:13062-13075. CrossRef Medline

Zhang Z, Ferretti V, Güntan İ, Moro A, Steinberg EA, Ye Z, Zecharia AY, Yu X, Vyssotski AL, Brickley SG, Yustos R, Pillidge ZE, Harding EC, Wisden W, Franks NP (2015) Neuronal ensembles sufficient for recovery sleep and the sedative actions of alpha 2 adrenergic agonists. Nat Neurosci 18: 553-561. CrossRef Medline 